\title{
Advances in the study of nodavirus
}

\author{
Chean Yeah Yong ${ }^{1}$, Swee Keong Yeap ${ }^{2}$, Abdul Rahman Omar ${ }^{1}$, Wen Siang Tan ${ }^{\text {Corresp. }}{ }^{3}$ \\ 1 Institute of Bioscience, Universiti Putra Malaysia, Serdang, Selangor, Malaysia \\ 2 Xiamen University Malaysia, Sepang, Selangor, Malaysia \\ 3 Department of Microbiology, Faculty of Biotechnology and Biomolecular Sciences, Universiti Putra Malaysia, Serdang, Selangor, Malaysia \\ Corresponding Author: Wen Siang Tan \\ Email address: wstan@upm.edu.my
}

Nodaviruses are small bipartite RNA viruses which belong to the family of Nodaviridae. They are categorized into alpha-nodavirus which infects insects and beta-nodavirus which infects fishes. Another distinct group of nodavirus infects shrimps and prawns, which has been proposed to be categorized as gamma-nodavirus. Our current review focuses mainly on recent studies performed on nodaviruses. Nodavirus can be transmitted vertically and horizontally. Recent outbreaks have been reported in China, Indonesia, Singapore and India, affecting the aquaculture industry. It also decreased mullet stock in the Caspian Sea. Histopathology and transmission electron microscopy (TEM) are used to examine the presence of nodaviruses in infected fishes and prawns. For classification, virus isolation followed by nucleotide sequencing are required. In contrast to partial sequence identification, profiling the whole transcriptome using next generation sequencing (NGS) offers a more comprehensive comparison and characterization of the virus. For rapid diagnosis of nodavirus, assays targeting the viral RNA based on reverse-transcription PCR (RT-PCR) such as microfluidic chips, reverse-transcription loop-mediated isothermal amplification (RT-LAMP) and RT-LAMP coupled with lateral flow dipstick (RT-LAMP-LFD) have been developed. Besides viral RNA detections, diagnosis based on immunological assays such as enzyme-linked immunosorbent assay (ELISA), immunodot and western blotting have also been reported. In addition, immune responses of fish and prawn are also discussed. Overall, in fish, innate immunity, cellular type I interferon immunity and humoral immunity cooperatively prevent nodavirus infections. Whereas prawns and shrimps adopt different immune mechanisms against nodavirus infections, through upregulation of superoxide anion, prophenoloxidase, superoxide dismutase (SOD), crustin, peroxinectin, anti-lipopolysaccharides and heat shock proteins (HSP). Potential vaccines for fishes and prawns based on inactivated viruses, recombinant proteins or DNA, either delivered through injection, oral feeding or immersion, are also discussed in detail. Lastly, a comprehensive review on nodavirus virus-like particles (VLPS) is presented. In recent 
years, studies on prawn nodavirus are mainly focused on Macrobrachium rosenbergii nodavirus (MrNV). Recombinant MrNV VLPs have been produced in prokaryotic and eukaryotic expression systems. Their roles as a nucleic acid delivery vehicle, a platform for vaccine development, a molecular tool for mechanism study and in solving the structures of MrNV are discussed intensively. 


\section{Advances in the study of nodavirus}

2

3 Chean Yeah Yong ${ }^{1}$, Swee Keong Yeap ${ }^{2}$, Abdul Rahman Omar ${ }^{1}$, and Wen Siang Tan ${ }^{3} *$

4

$5 \quad{ }^{1}$ Institute of Bioscience, Universiti Putra Malaysia, 43400 Serdang, Selangor, Malaysia. ${ }^{2}$ Xiamen

6 University Malaysia, 43900 Sepang, Selangor, Malaysia.

$7 \quad{ }^{3}$ Department of Microbiology, Faculty of Biotechnology and Biomolecular Sciences, Universiti

8 Putra Malaysia, 43400 Serdang, Selangor, Malaysia.

9

*Correspondence:

11 Wen Siang Tan

Department of Microbiology

13 Faculty of Biotechnology and Biomolecular Sciences

14 Universiti Putra Malaysia

1543400 Serdang, Selangor, Malaysia.

16 Tel: 603-89466715; Fax: 603-89430913

17 Email: wstan@upm.edu.my; wensiangtan@yahoo.com

19 ABSTRACT

21 Nodaviruses are small bipartite RNA viruses which belong to the family of Nodaviridae. They

22 are categorized into alpha-nodavirus which infects insects and beta-nodavirus which infects

23 fishes. Another distinct group of nodavirus infects shrimps and prawns, which has been proposed 
24 to be categorized as gamma-nodavirus. Our current review focuses mainly on recent studies

25 performed on nodaviruses. Nodavirus can be transmitted vertically and horizontally. Recent outbreaks have been reported in China, Indonesia, Singapore and India, affecting the aquaculture

27 industry. It also decreased mullet stock in the Caspian Sea. Histopathology and transmission electron microscopy (TEM) are used to examine the presence of nodaviruses in infected fishes and prawns. For classification, virus isolation followed by nucleotide sequencing are required. In contrast to partial sequence identification, profiling the whole transcriptome using next generation sequencing (NGS) offers a more comprehensive comparison and characterization of the virus. For rapid diagnosis of nodavirus, assays targeting the viral RNA based on reversetranscription PCR (RT-PCR) such as microfluidic chips, reverse-transcription loop-mediated isothermal amplification (RT-LAMP) and RT-LAMP coupled with lateral flow dipstick (RTLAMP-LFD) have been developed. Besides viral RNA detections, diagnosis based on immunological assays such as enzyme-linked immunosorbent assay (ELISA), immunodot and western blotting have also been reported. In addition, immune responses of fish and prawn are also discussed. Overall, in fish, innate immunity, cellular type I interferon immunity and humoral immunity cooperatively prevent nodavirus infections. Whereas prawns and shrimps adopt different immune mechanisms against nodavirus infections, through upregulation of superoxide anion, prophenoloxidase, superoxide dismutase (SOD), crustin, peroxinectin, antilipopolysaccharides and heat shock proteins (HSP). Potential vaccines for fishes and prawns based on inactivated viruses, recombinant proteins or DNA, either delivered through injection, oral feeding or immersion, are also discussed in detail. Lastly, a comprehensive review on nodavirus virus-like particles (VLPs) is presented. In recent years, studies on prawn nodavirus 46 are mainly focused on Macrobrachium rosenbergii nodavirus (MrNV). Recombinant $M r \mathrm{NV}$ 
47 VLPs have been produced in prokaryotic and eukaryotic expression systems. Their roles as a 48 nucleic acid delivery vehicle, a platform for vaccine development, a molecular tool for

49 50

\section{1}

52 53

54 mechanism study and in solving the structures of $M r \mathrm{NV}$ are discussed intensively.

\section{INTRODUCTION}

The current review discusses recent studies related to nodaviruses. Recent reported outbreaks of nodaviruses, diagnostic assays, host immunological responses, vaccines, and virus-like particles (VLPs) are emphasized. To the best of our knowledge, there are only 8 review articles related to nodavirus which had been published within the past 5 years: immunological-based detection of shrimp viruses (Chaivisuthangkura, Longyant \& Sithigorngul, 2014); recombinant nodavirus-like particles as delivery system (Jariyapong, 2015); the life cycle of beta-nodaviruses (Low et al., 2017); viral encephalopathy and retinopathy in aquaculture (Doan et al., 2017); interaction between beta-nodavirus and its host for development of prophylactic measures for viral encephalopathy and retinopathy (Costa \& Thompson, 2016); reactive oxygen species-mediated cell death (Reshi, Su \& Hong, 2014); mitochondrial disruption and necrotic cell death (Hong, 2013); and immunity to beta-nodavirus infections of marine fish (Chen, Wang and Chen, 2014).

Another two review articles published within the past 10 years are about the biology and biomedical applications of Flock House virus (Venter and Schneemann, 2008), and white-taildisease (WTD) in Macrobrachium rosenbergii (Bonami \& Sri Widada, 2011). However, none of these articles review the recent advances in the study of nodaviruses as presented in the current review. 
69

\section{SURVEY METHODOLOGY}

"PubMed" and "Scopus" were used to search for journal articles published within the recent 5 years using the keyword "nodavirus". These articles were screened and used as references for the current review. Additional information was obtained through the "Google" search engine with more specific keywords for older publications.

\section{Nodavirus}

into alpha-nodavirus and beta-nodavirus based on their hosts. Alpha-nodaviruses such as Nodamura virus (NoV), Flock House virus (FHV), black bettle virus (BBV), Pariacoto virus $(\mathrm{PaV})$, and a recently discovered mosinovirus (MoNV) (Schuster et al., 2014) infect insects, whereas beta-nodaviruses such as striped jack nervous necrosis virus (SJNNV), barfin flounder nervous necrosis virus (BFNNV), redspotted grouper nervous necrosis virus (RGNNV), and tiger puffer nervous necrosis virus (TPNNV) infect fishes. Another type of nodavirus infects prawn, it is distinctive from alpha- and beta-nodaviruses (NaveenKumar et al., 2013). This prawn nodavirus includes Macrobrachium rosenbergii nodavirus $(\mathrm{MrNV})$ and Penaeus vannamei nodavirus $(P v \mathrm{NV})$. NaveenKumar et al. (2013) proposed that the $M r \mathrm{NV}$ and $P v \mathrm{NV}$ should be categorized into gamma-nodaviruses, based on their distinct genomic sequences compared with that of both the alpha- and beta-nodaviruses. More recent studies have identified another two prawn nodaviruses, namely the covert mortality nodavirus (CMNV) (Zhang et al., 2014; Zhang et al., 2015) and Farfantepenaeus duorarum nodavirus (FdNV) (Ng et al., 2013), infecting Litopenaeus vannamei and F. duorarum, respectively. Although nodaviruses are usually named 
91 after their native hosts, nodaviruses are often capable of infecting multiple species. RGNNV has

92 been reported to infect Asian seabass, Lates calcarifer (Banerjee et al., 2014); Nile tilapia,

93 Oreochromis niloticus (Keawcharoen et al., 2015); and Amphiprion sebae Bleeker, a marine

94 clownfish (Binesh et al., 2013), whereas MrNV has also been reported to infect Penaeus indicus,

95 Penaeus monodon, and P. vannamei (Ravi et al., 2009; Senapin et al., 2012).

\section{Fish nodavirus}

The fish nodavirus, also known as Nervous Necrosis Virus (NNV), infects fishes and causes viral encephalopathy and retinopathy (VER). The first outbreak occurred in 1985 (Costa

\& Thompson, 2016). The infection was first described by Yoshikoshi \& Inoue (1990) in the Japanese parrot fish Oplegathus fasciatus. Fishes infected by nodavirus suffer neurological 102 disorders, which are characterized by intensive vacuolization of retina and central nervous systems, culminating in abnormal swimming pattern and darkening of fish color (Munday \& Nakai, 1997). In fish, Nodavirus can be detected in many organs but central nervous system including the brain, spinal cord and retina are the main targets (Ghiasi et al., 2016). The fish nodavirus seriously affects aquaculture industry worldwide, resulting in great economic losses. and juveniles (Skliris et al., 2001). To date, nodavirus is known to affect over 120 fish species, particularly groupers and seabass such as the Asian seabass Lates calcarifer and European seabass Dicentrarchus labrax (Breuil et al., 1991; Costa \& Thompson, 2016; Frerichs et al.,

111 1996; Munday et al., 2002; Parameswaran et al., 2008). Although nodavirus mostly affects

112 marine fishes, nodavirus infections in freshwater fishes such as European eels (Anguilla anguilla 
113 L.), yellow-wax pompano (Trachinotus falcatus), firespot snapper (Lutaanus erythropterus B.),

114 cobia (Rachycentron canadum) and Chinese catfish (Parasilurus asotus) have been reported in

115 Taiwan (Chi, Shieh \& Lin, 2003). In addition, outbreaks in hybrid striped bass $\mathrm{x}$ white bass

116 (Morone saxalitis x Morone chrysops) and largemouth bass (Micropterus salmoides) have also

117 been reported in Italy (Bovo et al., 2011). Apart from horizontal transmission, fish nodavirus can

118 be transmitted vertically through infections at the gonads, passing the virus to their progenies

119 (Breuil et al., 2002; Kocan et al., 2001; Valero et al., 2015a).

\section{Prawn nodavirus}

Like fish nodavirus, prawn nodavirus has significant economic impact on the prawn aquaculture industry. Prawn nodavirus can be isolated from cephalothoraxes and whitish abdominal muscle (Zhang et al., 2014) of infected prawns. The most studied prawn nodavirus is the $M r \mathrm{NV}$. It is a non-zoonotic nodavirus which infects $M$. rosenbergii, commonly known as the giant river prawn. $M r \mathrm{NV}$ was first isolated and reported in 1999 (Arcier et al., 1999) from $M$. rosenbergii. Infection by $M r \mathrm{NV}$ causes white tail disease (WTD) or white muscledisease (WMD), where infected cells undergo necrosis and turn whitish. The rate of mortality is extremely high (up to $100 \%$ ) in larvae and post-larvae of M. rosenbergii (Qian et al., 2003; Ravi et al., 2009), causing great economic losses to $M$. rosenbergii hatchery and nursery farm industries. Despite the high mortality rate in larvae and post-larvae prawns, $M r \mathrm{NV}$ does not cause death in adult prawns. However, the adult prawns still serve as the virus carriers,

133 transmitting the virus vertically to their offsprings (Sudhakaran et al., 2007), and horizontally to 134 other prawns during cannibalization (Sahul Hameed et al., 2004). Another prawn virus, $P v$ NV 
135 was first isolated in 2005 from a P. vannamei farm in Belize (Tang et al., 2007; Tang et al.,

136 2011). Being a prawn nodavirus, $P v \mathrm{NV}$ shares $83 \%$ similarities with $M r \mathrm{NV}$ in its viral genome

137 (Tang et al., 2011). It causes muscle necrosis, resulting in white, opaque lesions in the tail,

138 similar to the symptoms of $M r \mathrm{NV}$ infection. However, the virulence of $P v \mathrm{NV}$ is not as high as

$139 \mathrm{MrNV}$, in which the former normally resulted in approximately $50 \%$ production loss in an

140 infected farm (Tang et al., 2007). Apart from its native host, $P v \mathrm{NV}$ has also been demonstrated

141 to be able to infect Penaeus monodon in an experimental infection (Tang et al., 2007).

Insect nodavirus

Unlike fish and prawn nodaviruses, insect nodavirus does not have a direct impact on global economy. Despite that, insect nodavirus, especially the FHV and BBV have served as excellent models to study the mechanisms of other positive-strand RNA viruses, such as those of Caliciviridae, Flaviviridae, Picornaviridae, and Togaviridae, due to their small genome size and high level of replication in compatible hosts (Ball \& Johnson, 1998). FHV was originated from grass grub, Costelytra zealandica (Dearing et al., 1980). FHV has been demonstrated to be able to infect a wide variety of hosts, including insects, yeasts, plants, and mammalian cells. Apart from its original host C. zealandica, FHV also infects the common fruit fly, Drosophila melanogaster. Therefore, cell-lines derived from D. melanogaster such as Schneider Line 1

153 (DL1) have been established for the propagation of insect nodaviruses (Dearing et al., 1980; Miller, Schwartz \& Ahlquist, 2001). When the yeast Saccharomyces cerevisiae was transfected

155 with FHV, the viral genomic RNA induced the production of infectious virion capable of 156 infecting Drosophila cells (Price, Rueckert \& Ahlquist, 1996). In addition, FHV was also 
157 reported to infect the whole plants of barley, cowpea, chenopodium and tobacco (Selling, Allison

158 \& Kaesberg, 1990), as well as mammalian cells such as the baby hamster kidney cell (BHK21)

159 (Ball, Amann \& Garrett, 1992). Due to its wide host range, FHV has been an excellent model to 160 study the mechanisms of other economically important RNA viruses. Another well-studied insect 161 virus, BBV, was isolated from Heteronychus arator. BBV propagates well in Drosophila line 1 162 cells, but not in BHK21, mouse L-cell, mosquito cells (Aedes albopictus and A. aegypti), 163 cabbage looper (Trichoplasia ni), fall armyworm (Spodoptera frugiperda) and line GM1 of $D$. 164 melanogaster (Friesen et al., 1980). Selling \& Rueckert (1984) established a plaque assay for 165 nodaviruses using Drosophila cell-adapted BBV, which greatly facilitates the isolation and 166 reassortant of nodaviruses (Kopek et al., 2010; Settles and Friesen, 2008). BBV's structure has 167 been studied intensively using electron microscopy and crystallization followed by small-angle 168 x-ray scattering (Hosur et al., 1984). As in other nodaviruses, BBV appeared to form icosahedral 169 structure with a triangulation number of $T=3$. Furthermore, the RNA3 of nodavirus was 170 identified to be a subgenomic mRNA of the viral RNA1 by studying BBV, and it can be isolated 171 from cells infected by BBV (Friesen and Rueckert, 1982; Guarino et al., 1984). Another insect 172 nodavirus, Boolarra virus was isolated from ghost moth Oncopera intricoides (Reinganum, 173 Bashiruddin \& Cross, 1985). The viral morphogenesis was shown to be restricted to the 174 cytoplasm of cultured Drosophila cell lines (Bashiruddin \& Cross, 1987). A more recent Wuhan 175 nodavirus was isolated from Pieris rapae larvae (Liu et al., 2006a). A study of its subgenomic 176 RNA3 has provided an insight into the RNAi inhibitory property of the nodavirus B2 protein 177 (Cai et al., 2010). 
In general, nodaviruses are non-enveloped zoonotic viruses with icosahedral structures.

181 Their genomes comprise of two linear, positive-sense, single-stranded RNA. RNA 1 is

182 approximately 3.1-3.2 kilobases $(\mathrm{kb})$ in length, whereas RNA2 is approximately $1.2-1.4 \mathrm{~kb}$.

183 Both of which lack a poly-A tail at their 3' ends (Comps, Pepin \& Bonami, 1994; Mori et al.,

184 1992). RNA 1 encodes for the RNA-dependent RNA polymerase (RdRP), which functions in

185 replicating the viral RNA genome without involving an intermediate DNA. RNA 3, a 186 subgenomic transcript of RNA 1, it encodes for a non-structural B2-like protein (Cai et al., 2010;

187 Hayakijikosol \& Owens, 2012; Lingel et al., 2005). B2 functions as a suppressor for the post188 transcriptional gene silencing of host defense mechanisms through non-specific binding to

189 double-stranded RNA generated during the virus replication (Fenner et al., 2006). RNA 2 190 encodes for the viral capsid protein, which forms the core of nodavirus. The nodavirus capsid 191 protein assembles into virus particles with icosahedral structures, approximately $30 \mathrm{~nm}$ in 192 diameter, with a triangulation number of $3(T=3)$ containing 180 capsid subunits. The virus 193 particles package only the RNA 1 and RNA 2, forming simple but infectious virions.

\section{Transmission of nodavirus}

It has been confirmed that vertical transmission is the main mechanism of nodavirus spreading (Murwantoko et al., 2016; Zhang et al., 2017). This vertical transmission in the aquaculture industry can be overcome by good biosecurity practices in hatchery-reared larvae and juveniles of some fish species. Besides vertical transmission, nodavirus may also infect the cultured fish even at the grow-out stages through horizontal transmission. Although nodaviruses detected in aquaculture farms are often with relatively low sequence variations, PCR based 
203 with high numbers of sequence variations in wild fishes and even seawater samples. This implies

204 that, nodavirus with different virulence may be shed by the less susceptible wild fish in water

205 and consequently virulent forms of nodavirus in the seawater would infect the susceptible

206 cultured fish (Nishi et al., 2016).

207

208

\section{Recent incidence of nodavirus}

209

Nodavirus infection has a great negative impact on the aquaculture industry. To date, more than 40 marine and freshwater fish species have been identified susceptible to nodavirus (particularly betanodavirus) infection (Nishi et al., 2016). It has been detected in freshwater prawn hatcheries in Indonesia (Murwantoko et al., 2016) and marine shrimp farms located in Fujian, Shandong and Hebei Provinces in China (Zhang et al., 2014). In addition, nodavirus caused mass mortality in cage-reared freshwater guppy Poicelia reticulate in Singapore (Hegde et al., 2003), larval rearing facility of marine clownfish, Amphiprion sebae in India (Binesh et al., 2013) and Asian seabass in India (Banerjee et al., 2014). Apart from affecting aquaculture industry, nodaviruses detected in wild golden grey mullet Liza aurata and sharpnose mullets Liza saliens were correlated to the dramatically decrease of mullets stock in Caspian Sea (Zorriehzahra et al., 2014; Ghiasi et al., 2016).

\section{Detection of nodavirus}

\section{General identification}

Histopathology and Transmission Electron Microscopy (TEM) examinations were used

224 to observe the presence of nodaviruses in fishes (Ghiasi et al., 2016) and shrimps (Zhang et al., 225 2014). In terms of histopathological analysis of nodavirus infected shrimps, necrotic epithelium 
226 and inclusions in the hepatopancreatic tubular epithelium are commonly observed in a nodavirus

227 infected shrimp. In addition, viral inclusion and viral particles are commonly observed in the

228 hepatopancreas using TEM (Zhang et al., 2014). Moreover, severe anemia associated with

229 increase of neutrophil populations, decrease of lymphocyte populations, raise of liver enzyme

230 profile and decline of total protein, albumin and total immunoglobulin levels were also observed

231 in fishes infected with nodaviruses (Ghiasi et al., 2016).

232

\section{Molecular identification}

For the phylogenetic analysis, conventional and real-time reverse transcription PCR (RTPCR) that amplify the RNA-dependent RNA polymerase (RdRp) of RNA 1 (Murwantoko et al., 2016) or the T4 region of RNA2 of nodavirus (Nishizawa et al., 1994; Hegde et al., 2003; Banerjee et al., 2014; Overgård et al., 2012), random shotgun metagenomic sequencing (Ng et al., 2013) and Illumina whole transcriptome metagenomic sequencing were able to detect the presence of nodavirus in infected organisms (Greninger \& DeRisi, 2015) or even from seawater (Nishi et al., 2016). For example, tombunodavirus that shares nucleotide sequence similarity with that of nodavirus and tombuvirus family members was identified in the weekly metagenomic sequencing of organisms in San Francisco wastewater (Greninger and DeRisi, 2015).

Nevertheless, whether this phenomenon was due to co-infection of nodavirus and tombuvirus or the real existence of tombunodavirus needs further validation. In another study by ConceiçãoNeto et al. (2015), putative novel member of nodavirus was detected in the fecal samples of otter (Lutra lutra) in Portugal based on the identification of RdRp in the metagenomic analysis.

247 However, this nodavirus identified in the gut of the otter maybe originated from a fish diet, 248 which doubted the report of a new host for nodavirus (Conceição-Neto et al., 2015). 

sequencing or next generation sequencing (NGS) allow specific characterization of a particular

251

252

253

254

255

256

257

258

259

260

261

262

263

264

265

266

267

268

269

270 strain of nodavirus (Zhang et al., 2014). Based on the International Committee on Taxonomy of Viruses (ICTV), isolated nodaviruses can be classified according to the genetic diversity of the RNA2 segment by the simple and cost-effective Sanger sequencing method (Conceição-Neto et al., 2015). Pairwise identity of the RNA2 with less than $80 \%$ at the nucleotide level and less than $87 \%$ at the amino acid level is classified as a novel species (Schuster et al., 2014). Comparing to the partial sequence identify determined by the Sanger sequencing method, profiling the whole transcriptome of a nodavirus offers a more comprehensive comparison and characterization of the virus classification. For example, CMNV, an alphanodavirus that shares only 31-54\% nucleotide sequence similarity with other nodaviruses in the GenBank, was successfully characterized by sequencing the cDNA library using the Roche 454 sequencer (Zhang et al., 2014). In addition, fluorescence in situ hybridization (FISH) and nested RT-PCR assays that detect a specific nodavirus can be designed (Zhang et al., 2014). Another study by Schuster et al. (2014) reported the identification of Mosinovirus (MoNV), a novel member of the family Nodaviridae, neither belongs to alpha- nor beta-nodaviruses. Without the isolation of the virus, recombination that was detected by the whole transcriptome 454 pyrosequencing in MoNV would not be accepted (Schuster et al., 2014). Although nodavirus can be detected in water samples, quantitative isolation of the nodavirus remains challenging with the current available protocols (Nishi et al., 2016).

\section{Diagnosis of nodaviruses}



the detection of piscine nodavirus in groupers has been developed (Kuo et al., 2012). The microfluidic chip contains an RT-PCR module capable of processing extracted RNA samples, and a capillary electrophoresis module. This microchip has been field-tested in an epidemiological investigation of NNV in Taiwan (Kuo et al., 2012).

Reverse-transcription loop-mediated isothermal amplification (RT-LAMP) is another potential point-of-care diagnostic assay, as a laboratory setup such as thermocycler and electrophoresis equipment can be omitted. Suebsing, Prombun \& Kiatpathomchai (2013) developed an RT-LAMP with colorimetric gold nanoparticle probe assay for the detection of PvNV in P. vannamei and P. monodon. This assay is 10x more sensitive than the nested RT-PCR established by Tang et al. (2007). On the other hand, Zhang et al. (2017) used the RT-LAMP as a rapid and quantitative diagnostic assay for the detection of $\mathrm{CMNV}$ in $P$. vannamei. This assay is capable of detecting as little as $6.3 \mathrm{pg}$ of total RNA from infected shrimps.

Assays based on lateral flow strips have also been deployed for diagnosis of nodavirus. Lin et al. (2014) combined RT-LAMP with a lateral flow dipstick (RT-LAMP-LFD) for the detection of $M r \mathrm{NV}$, targeting six distinct regions of $M r \mathrm{NV}$ RNA2. The sensitivity of this RTLAMP-LFD is 10x higher than that of the RT-LAMP. Toubanaki, Margaroni \& Karagouni (2015b) also developed a lateral flow paper biosensor for the detection of NNV in European seabass. Instead of RT-LAMP, this lateral flow biosensor detects the viral RNA through RTPCR using a 5'-biotin-tagged primer, a probe containing a poly-A tail, and gold nanoparticles 
294 reported to detect 270 pg of initial total RNA, which is less sensitive than the RT-LAMP based $295 \operatorname{method}(6.3 \mathrm{pg})$.

Apart from simply detecting the presence of nodavirus infection, it is also important to

297

298

299

300

301

302

303

304

305

306

307

308

309

310

311

312

313

314

315

identify the genotype of the infecting virus, either for epidemiological study, or for specific strategy design to eliminate virus infection in an aquaculture farm. Toubanaki, Margaroni \& Karagouni (2015a) developed a tetra-primer PCR which can amplify specifically RGNNV or SJNNV cDNA, thereby generating short PCR products of different sizes which can distinguish between RGNNV and SJNNV infections in European seabass.

Apart from detecting the virus at RNA level, the presence of nodavirus can also be evaluated by immunological methods, such as western blotting, indirect florescent antibody, enzyme-linked immunosorbent assay (ELISA) and immunodot blot tests (Ghiasi et al., 2016; Hegde et al., 2003; Sri Widada et al., 2003). MrNV infection has been diagnosed with western blotting, dot blot and ELISA using polyclonal antibodies against the recombinant $M r \mathrm{NV}$ capsid protein raised in rabbit (Farook et al., 2014a). Wang, Chang \& Wen (2016) used an immunodot blot assay to detect $M r \mathrm{NV}$ with a polyclonal antibody raised against the recombinant viral capsid in a Wistar rat. In addition, Wangman et al. (2012) successfully produced monoclonal antibodies that bind specifically to $M r \mathrm{NV}$ capsid protein. These antibodies can be used to detect $M r \mathrm{NV}$ without cross-reaction with other common shrimp viruses. Although the immunological methods are less sensitive compared with the viral RNA-based detection methods, the former remains a viable alternative for many laboratories.

\section{In vitro model for nodavirus studies}


317 virology, cell lines have been widely used to determine the infectivity, pathogenicity and

318 infectious mechanisms of nodavirus (Abdul Majeed et al., 2013; Nishi et al., 2016). Currently,

319 Channa striatus kidney (CSK) (kidney of Channa striatus), GB (brain of Epinephelus coioides),

320 GF-1 (fin of Epinephelus coioides), SSN-1 (fry of Ophicephalus striatus), E-11 (clone of SSN-1),

321 SISK (kidney of Lates calcarifer), SISS (spleen of Lates calcarifer), SIGE (eye of Epinephelus

322 coioides), ICF (fin of Clarias batrachus), IEE (eye of Etroplus suratensis), IEG (gill of Etroplus

323 suratensis), IEK (kidney of Etroplus suratensis), and IGK (kidney of Epinephelus coioides) fish

324 cell lines were proven susceptible to nodavirus infections and thus suitable for in vitro

325 propagation and studies of the viral infectious mechanisms (Abdul Majeed et al., 2013; Chi, Hu

326 \& Lo, 1999; Sarath Babu et al., 2013; Kai, Wu \& Chi, 2014; Nishi et al., 2016). Among these

327 cell lines, SISK, SISS and SIGE were found more susceptible to nodavirus infections and thus

328 they are suitable models for nodavirus propagation, diagnostic reagent and vaccine productions

329 (Sarath Babu et al., 2013).

\section{Immune response against nodavirus infection}

Immunity plays an important role in the prevention and recovery of nodavirus infection in

aquatic animals. Overall, activation of innate immunity (such as NK cells and antimicrobial peptides), cellular T cell type I interferon immunity, and humoral immunity (immunoglobulins antibodies) cooperatively prevent nodavirus infection (Chen, Wang \& Chen, 2014; Costa \& of well-developed adaptive immune cells as present in adult fishes that restrict the viral 
338 replication, thus minimize the development of pathological and clinical signs (Overgård et al., 339 2012).

Pathogen-associated molecular patterns (PAMPs) on RNA viruses are first recognized by

341 pattern-recognition receptors (PRRs). This process subsequently induces intracellular signals to

342 activate defensive mechanisms (Chen et al., 2014). Toll-like receptors (TLRs) and retinoic acid-

343 inducible gene I (RIG-I)-like receptors (RLRs) are the two important classes of PRRs that sense

344 the PAMPs of RNA viruses such as fish nodaviruses (Chen et al., 2014; Costa and Thompson,

345 2016). The RLR family consists of RIG-1, melanoma differentiation-associated gene 5 (MDA-5)

346 and Laboratory of Genetics and Physiology 2 (LGP2). Activation of RLRs and TLRs

347 subsequently promotes interferon type I antiviral immune response (Costa and Thompson, 2016).

348 RLRs, MyD88-dependent TLRs (Chen et al., 2015) and TLR7 (Takano et al., 2011) were found

349 upregulated and correlated with the production of type I interferon and pro-inflammation

350 response. MDA5 is a member of RLRs that promotes transcription of interferon related immune

351 factors, which include interferon regulatory factor 3 (IRF3), IRF7 (Yu et al., 2017), and

352 interferon-stimulated response element (ISRE) such as interferon-stimulated gene 15 (ISG15)

353 (Huang et al., 2013) and proinflammatory cytokines (Huang et al., 2016b). Unlike RIG-1 and

354 MDA-5, the exact functions of LGP2 in different virus infections are controversial. LGP2 is

355 generally reported as a positive regulator of RIG-1 and MDA-5 (Chen et al., 2014). However, a

356 recent study showed a contrary function of LGP2, in which the overexpression of LGP2

357 suppressed the expression of MDA5, Mx promoter, ISRE, pro-inflammatory cytokines and type I

358 interferon genes, thus resulting in a high viral load (Yu et al., 2016).

Tripartite motif-containing (TRIM) proteins are multi-domain proteins that exert

important immune regulatory roles on TLR and RLRs mediated antiviral innate immunity 
361 (Huang et al., 2016a). The innate antiviral immunities of fish against nodavirus infection are

362 summarized in Fig. 1. In fish, TRIM proteins play an important role in recognition and initiation

363 of protection against nodavirus infection. To date, fish TRIM25, TRIM32 and TRIM39 exerted

364 positive antiviral responses via activation of MDA5 expression (Wang et al., 2016b; Yang et al.,

365 2016; $\mathrm{Yu}$ et al., 2017). On the other hand, TRIM13 exerted negative regulation on antiviral

366 immunity against nodavirus infection through downregulation of MDA5 and the downstream

367 IFN signaling pathway (Huang et al., 2016a).

368 Type I $(\alpha / \beta)$ and type II $(\gamma)$ interferons play important roles in the innate immune

369 responses against nodavirus infection in fish. Post detection by PRRs, IFN type I will be secreted

370 and picked up by IFN receptor of neighboring cells, activating its Janus kinases 1 (JAK1)/signal

371 transducer and activators of transcription (STAT) pathway which leads to the transcription of

372 IFN-stimulated genes (ISGs) (Chen et al., 2014) and pro-inflammatory cytokines, such as IL-1 $\beta$,

373 IL-6 and TNF- $\alpha$ (Costa and Thompson, 2016). Activation of ISGs via type I interferon

374 subsequently promotes Mx promoter activity, which increases host resistance to nodavirus

375 infection (Chen et al., 2014). Mx is one of the downstream antiviral effectors under type I

376 interferon immunity (Sadler and Williams, 2008). The researchers demonstrated that the

377 sevenband grouper Epinephelus septemfasciatusu pre-treated with non-lethal aquabirnavirus

378 (ABV) developed a protection against the RGNNV nodavirus infection prior to the activation of

379 type I interferon. This protection was attributed to the overexpression of the type I interferon

380 downstream effector, the Mx gene in head kidney and brain of the fish (Pakingking Jr et al.,

381 2005). Furthermore, inoculation of gilthead seabream Sparus aurata with lipopolysaccharides

382 from Vibrio alginolyticus also stimulated the Mx gene expression in liver, which effectively

383 reduced the load of nodavirus in the brain (Bravo et al., 2013). 
384 Halibuts and groupers are known reservoirs of nodavirus but resistant to the virus and vertically

385 transmit the disease (Chaves-Pozo et al., 2012; Overgård et al., 2012). Although the early 386 proinflammatory type 1 interferon response helps to control the nodavirus infection in the 387 juvenile Atlantic halibut Hippoglossus hippoglossus, the viral RNA was still detected in the brain, 388 eye and head kidney of the fish even after 14 weeks post infection by the virus. This was 389 accompanied by more drastic $\mathrm{T}$ cell mediated responses including upregulation of the $\mathrm{T}$ cell 390 markers (CD4, CD8 $\alpha$ and CD8 $\beta$ ), ISG15, Mx and IFN $\gamma$ genes expression (Overgård et al., 2012). However, elevation of proinflammatory cytokines without significant changes in CD4, CD8 $\alpha$ 392 and CD8 $\beta$ T cell markers was observed in the brain, eye and head kidney of Atlantic halibut at the early stage of nodavirus infection (Overgård et al., 2012). On other hand, susceptible species such as European seabass was detected with delayed but stronger proinflammatory response, resulting in an irreparable brain damage (Poisa-Beiro et al., 2008; Valero et al. 2015b). In addition, a challenge study on sensitive seabass species with low titer of nodavirus induced early but short-term type I interferon response (Scapigliati et al., 2010). Moreover, Valero et al. (2015a) showed that nodavirus replicated more in the reservoir seabream's testis than the susceptible seabass, through modulation of reproductive system that favor the transmission and shedding of the virus in the reservoir species. This result indicates that proinflammatory type I interferon did not involve in stimulating $\mathrm{T}$ cell proliferation at the early stage of the viral infection, and thus $\mathrm{T}$ cell type I interferon response is not sufficient to clear the nodavirus, resulting in vertical virus transmission in the reservoir species. The researchers proposed that antimicrobial peptides 404 (AMPs) play an important role in vertical transmission of nodavirus in resistant fish species (Valero et al., 2015b). AMPs are a major component of the innate immune system in fish that 406 activate antiviral effects upon nodavirus infection (Xie, Wei \& Qin, 2016; Valero et al., 2015b). 
407 Grouper epinecidin-1 (CP643-1), complement factor 3 (c3), lysozyme (lyz), hepcidin (hamp), 408 dicentracin (dic), piscidin (pis) or b-defensin (bdef) are AMPs found to be activated during 409 nodavirus infection in both susceptible and resistant fish species (Valero et al., 2015b). CP643-1 410 was also reported to induce the Mx gene expression during nodavirus infection in fish (Chia et al. 411 2010). In addition, Tachyplesin I has been reported as an AMP found in resistant grouper strains 412 which activates the antivirus activity through promotion of ISRE and IFN- $\beta$ expression (Xie, 413 Wei \& Qin, 2016). Histones (H1 to H4) are another type of potential AMPs that may play some 414 roles in the antiviral effects in fish. However, more studies are needed to investigate the function 415 of histones in protecting fish against nodavirus infection (Valero et al., 2016a). Production of AMPs in resistant gilthead seabream and susceptible European seabass differs significantly, in which the AMPs were highly expressed in the brain but low in the gonad of gilthead seabream, whereas in European seabass it was highly expressed in the gonad but low in brain. These results indicate that vertical transmission of nodavirus by the resistant gilthead seabream could be attributed to the poor AMP response in the gonad. The European seabass containing a high level of AMPs in the gonad did not survive nodavirus infection as the AMP expression level in the

422 brain was low (Valero et al., 2015b). There are other immune factors contribute to the protection of fish against nodavirus infection. Esteban et al. (2013) reported that nodavirus strain 411/96 (RGNNV) induced early (day 1 post-challenged) expression of the peroxiredoxin natural killer enhancing factor A (NKEF-A), which involved in inflammation and innate immunity in both the brain and head 427 kidney of gilthead seabream, but not in European seabass. This result shows that an early expression of NKEF-A which activates immune cells including the NK cells and macrophages is 429 an important anti-nodavirus mechanism in resistant species. On the other hand, the involvement 
430 of CD83 gene in the immune response of fish during nodavirus infection was also evaluated.

431 Downregulation of CD83-like molecule expression was observed in the head kidney of European

432 seabass post-infected with nodavirus. Although CD83 was known as a marker for matured

433 human dendritic cells, active thymic T cells and even B cells, the exact function of CD83 in fish

434 lymphocytes is still unknown (Buonocore et al., 2012). Thus, more studies have to be performed

435 to investigate the involvement of CD83 expression in immunity against nodavirus infection.

436 Nodavirus is a simple RNA virus with only 3 genes. However, it has developed some

437 virus-host interaction properties, which include hijacking the host system and escaping host

438 defense mechanism (Chen et al., 2014). Overexpression of heat shock transcription factor 1

439 (HSF1) promoted the replication of nodavirus at the initial stage of the viral infection, which

440 could be due to an increase of fish body temperature as the expression of Mx protein was

441 suppressed at high temperature condition (Wang, Chen \& Chen, 2016). Suppression of HSF1 by

442 the heat shock protein 90 (HSP90) thereby reduced the replication of nodavirus during the initial

443 stage of the viral infection (Chen et al., 2010; Wang, Chen \& Chen, 2016). Moreover, fish is

444 more susceptible to nodavirus infection in the present of immunosuppressive agents. Lawrence,

445 Reid \& Whalen (2015) reported that an organotin compound, tributyltin, which is commonly

446 used as antifouling paints for ships and fishing nets caused immune suppression in fishes.

447 Exposure of Japanese medaka Oryzias latipes larvae to tributyltin increased their susceptibility

448 towards SGWak97 nodavirus (RGNNV) infection, which resulted in a higher mortality in a

449 dosage dependent manner. This phenomenon could be attributed to the immunosuppression

450 caused by tributyltin on fish NK cell activity (Kitamura et al., 2017).

451 Besides innate and cell mediated immunity, humoral immunity also plays an important

452 role in protecting fish against nodavirus infection (Chen et al., 2014), especially the two 
453 immunoglobulins, IgM and IgT. Infection of susceptible seabass with low titer of nodavirus did

454 not significantly alter the expression of $\operatorname{IgM}$ and IgT in the gills and spleen (Buonocore et al., 455 2017) but only induced a marginal increase of serum IgM (Scapigliati et al., 2010). On the other 456 hand, activation of $\operatorname{IgM}^{+}$and $\operatorname{IgT}^{+} \mathrm{B}$ cells in the brain and overexpression of soluble $\operatorname{IgT} \mathrm{T}^{+}$by $\mathrm{B}$ 457 cells in the head kidney by early inflammatory response in the central nervous system reduced 458 nodaviral replication in the resistant aquaculture-relevant fish species (Lopez-Munoz, 2012; 459 Piazzon et al., 2016). Thus, activation of IgM and IgT expression by vaccination can protect the 460 fish from nodavirus infection (Costa and Thompson, 2016). infection is even limited. Based on current findings, prawns generally fight infections through non-specific innate immune responses including prophenoloxidase-activating system (Ourth \& Renis, 1993; Popham et al., 2004) and over accumulation of superoxide anion (Ravi et al., 2010), which were known to inactivate DNA and RNA viruses. However, the basic understanding on the prawn immunity against nodavirus infection has ignited a spark of interest among researchers to produce vaccines against the prawn nodavirus. Instead of the whole virus, Farook et al. (2014b) introduced a recombinant $M r \mathrm{NV}$ capsid protein (r-MCP) produced in E. coli into M. rosenbergii as a potential vaccine against the WTD. This r-MCP increased the level of prophenoloxidase, 470 superoxide anion, and other anti-viral compounds such as crustin, peroxinectin, anti471 lipopolysaccharides and heat shock proteins (HSP21, HSP70, HSP90), which protected the $M$. 472 rosenbergii post-larvae from $\mathrm{MrNV}$ challenge up to $76 \%$.

473

\section{Advances in nodavirus vaccine development}


476 in aquaculture industry (Pakingking Jr et al., 2010). Table 1 summarizes the studies on nodavirus

477 vaccines. Among different types of vaccines, virus-like particles (VLPs) show the highest

478 potential to induce a long lasting and protective humoral immunity (Liu et al., 2006b).

479 Intramuscular administration of recombinant DGNNV VLPs produced in E. coli induced a high

480 antibody titer which is capable to neutralize the virus in vitro. Even without an adjuvant, 481 neutralizing antibodies induced by the DGNNV VLPs lasted over 5 months, further justifying the 482 potential application of nodavirus VLPs as a vaccine. A recombinant betanodavirus capsid 483 protein r-FNCP42 was generated by Vimal et al. (2014) based on the gene sequence of a fish 484 nodavirus isolated from Asian seabass (L. calcarifer) larvae. Intramuscular injection of $50 \mu \mathrm{g}$ r485 FNCP42/fish resulted in $75 \%$ survival of juveniles of Asian seabass challenged with $1 \times 10^{6.5}$ $486 \mathrm{TCID}_{50}$ of nodavirus. As the genome sequence of r-FNCP42 shares more than $98-99 \%$ similarity 487 with other fish nodaviruses including red spotted grouper nervous necrosis virus, Dicentrarchus 488 labrax encephalitis virus, Asian seabass nervous necrosis virus, and Epinephelus tauvina nervous necrosis virus (ETNV), thus cross protectivity of r-FNCP42 against these nodaviruses should be tested. Naveen Kumar, Karunasagar \& Karunasagar (2013) immunized M. rosenbergii through oral administration of inactivated bacteria encapsulated dsRNA of $M r \mathrm{NV}$ and XSV, where a 492 post-feeding virus challenge showed promising results. The $M r \mathrm{NV}$ challenge at $24 \mathrm{~h}$ and $72 \mathrm{~h}$ 493 post-feeding showed relative high percentage of survival at $80 \%$ and $75 \%$, respectively, 494 indicating a regulation via RNA interference. Ramya et al. (2014) used chitosan conjugated 495 DNA vaccine, where XSV antisense (XSVAS) nucleotide sequence was cloned into the pcDNA plasmid vector. The presence of plasmid pcDNA-XSVAS was confirmed after 30 days of 497 administration through oral feeding, where it provided approximately $50 \%$ protection to prawns 
498 challenged with crude extract of WTD-prawns. In addition, introduction of recombinant $M r \mathrm{NV}$

499 capsid protein through $24 \mathrm{~h}$ immersion followed by $M r \mathrm{NV}$ challenge boosted the relative percent

500 survival of prawns by $76.03 \%$ (Farook et al., 2014b).

501

502 Virus-like particles

503 After decades since nodaviruses were first discovered, studies on their VLPs continue.

504 DGNNV VLPs produced in E. coli were crystallized and studied with x-ray diffraction, revealing

505 a $T=3$ icosahedral structure approximately $38 \mathrm{~nm}$ in diameter, closely resembling the native

506 virion (Luo et al., 2014). Recombinant FHV capsid protein produced in E. coli was also used in

507 an in vitro assembly study (Bajaj \& Banerjee, 2016). The capsid protein possesses additional N-

508 terminal tag which hinders the assembly of the capsid protein into VLPs. Cleavage of this N-

509 terminal region in vitro in the presence of $\mathrm{Ca}^{2+}$ ion allows the capsid protein to assemble into

510 VLPs of different sizes. Despite the heterogenicity, these VLPs were capable of membrane

511 disruption, a property required by the nodavirus to penetrate its host cells (Bajaj \& Banerjee, 512 2016).

In addition, FHV VLPs have also been used to display foreign epitopes, such as that of

514 hepatitis C virus (HCV) (Peng, Dai \& Chen, 2005). Chen et al. (2006) used FHV VLPs to

515 display the epitopes of HCV core protein and hepatitis B virus (HBV) surface antigen, where the

516 displayed epitopes were shown to be immunogenic in guinea pigs. In another study, Manayami

517 et al. (2007) fused the protective antigen-binding von Willebrand A domain of ANTXR2 cellular

518 receptor to FHV VLPs. The researchers demonstrated that the fusion protein inhibited lethal

519 anthrax toxin, and at the same time induced toxin-neutralizing antibody which protected rats

520 from anthrax lethal toxin challenge. All of these studies demonstrated the potential of insect 
521 nodavirus VLPs as a foreign epitope presenting agent. In recent years, however, studies on

522 nodavirus VLPs focused more on the prawn nodavirus, particularly $M r \mathrm{NV}$.

The first prawn nodavirus VLPs were produced by Goh et al. (2011) via recombinant

524 DNA technology. The recombinant $M r \mathrm{NV}$ capsid protein expressed in $E$. coli self assembles into

525 VLPs of approximately $30 \mathrm{~nm}$ in diameter (Goh et al., 2011). Recently, they reported that 20-29

526 amino acids (a.a.) at the $\mathrm{N}$-terminal region of $M r \mathrm{NV}$ capsid protein are responsible for RNA

527 binding during the VLPs assembly through ionic interaction, where mutation of positively

528 charged a.a. at this region to alanine abolished the RNA binding of the $M r \mathrm{NV}$ capsid protein

529 (Goh et al., 2014). Despite the role of RNA binding, the N-terminal region (1-29 a.a.) is not 530 required for the assembly of the VLPs, as demonstrated by Goh et al. (2014). Jariyapong et al.

531 (2014) demonstrated the ability of the $M r \mathrm{NV}$ VLPs to encapsidate plasmid DNA in $0.035-$

$5320.042 \mathrm{~mol}$ ratio (DNA/ protein) through particle disassembly and reassembly, with the use of

533 EGTA [ethylene glycol-bis(2-aminoethylether)-N,N,N',N'-tetraacetic acid] and $\mathrm{Ca}^{2+}$ ion, thereby

534 opening a path for the MrNV VLPs to be used for the delivery of nucleic acid based therapeutic 535 agents, such as DNA vaccine or siRNA.

536

VLPs have been widely used for displaying foreign epitopes, for instance the VLPs of

537 human papilloma virus (Matic et al., 2011), HBV (Ibañez et al., 2013; Murray and Shiau, 1999;

538 Yap et al., 2012), as well as bacteriophages (Hashemi et al., 2012; Kok et al., 2002; Tan et al.,

539 2005; Wan et al., 2001). VLPs are known to enhance the immunogenicity of small epitopes

540 displayed on the particles (Murata et al., 2003; Quan et al., 2008). We have displayed the

541 immunodominant region of $\mathrm{HBV}$ on the surface of the $M r \mathrm{NV}$ VLPs through fusion at the C-

542 terminal end of $M r \mathrm{NV}$ capsid protein and confirmed the fusion protein with immunogold TEM

543 (Yong et al., 2015a). When introduced into BALB/c mice, this recombinant VLPs induced the 
544 production of anti-HBV antibodies, as well as the cellular immune responses including natural

545 killer cells, cytotoxic T lymphocytes (CTL) and IFN $\gamma$. In addition, we have fused and displayed

546 multiple copies of influenza A virus matrix 2 ectodomain (M2e) on the surface of the $M r \mathrm{NV}$

547 VLPs (Yong et al., 2015b). The displayed M2e epitopes were highly antigenic and

548 immunogenic, where they correlated well with the copy number of M2e displayed on the surface

549 of the VLPs. Most recently, Somrit et al. (2017) showed that the C-terminal region of $M r \mathrm{NV}$

550 capsid protein is exposed on the surface of the VLP, constituting the core of the viral capsid

551 protrusion, through a homology-based modeling based on cucumber necrosis virus. When the C-

552 terminal region was removed with chymotrypsin digestion, the internalization capability of the

553 truncated VLPs into Sf9 cells reduced significantly, suggesting the importance of the C-terminal

554 region in the viral infection.

555 In an attempt to discover the possible mechanism of $M r \mathrm{NV}$ infection pathway, we used 556 the $M r \mathrm{NV}$ VLPs labeled with fluorescein as a model to study the $M r \mathrm{NV}$ entry and localization in

557 Sf9 cells (Hanapi et al., 2017). Through the use of endosomal inhibitors coupled with laser 558 confocal microscopy and live cell imaging, we demonstrated that the internalization of $M r \mathrm{NV}$ 559 VLPs was facilitated by clathrin- and caveolae-mediated endocytosis. We have also identified a 560 potential nuclear localization signal (NLS), which could aid in the localization of $M r \mathrm{NV}$ capsid 561 protein to the nucleus based on the importin- $\alpha$ pathway (Hanapi et al., 2017).

Apart from the $M r \mathrm{NV}$ VLPs produced in E. coli, we have also produced the $M r \mathrm{NV}$ 563 capsid protein in Sf9 cells through baculovirus expression system (Kueh et al., 2017). This 564 eukaryotic produced $M r \mathrm{NV}$ capsid protein self-assembles into VLPs significantly larger than 565 their prokaryotic counterparts. The Sf9 produced MrNV VLPs are structurally more homogenous 566 as observed by TEM, representing a better candidate to be used in structural study. Subsequently, 
567 we used this $M r \mathrm{NV}$ VLPs produced in $\mathrm{Sf9}$ for 3D structure reconstruction using the images

568 obtained from cryogenic electron microscopy (Ho et al., 2017). The 3D structure of $M r \mathrm{NV}$

569 capsid at 7 Angstroms resolution reveals a $T=3$ icosahedral structure distinctive to other insect

570 and fish nodavirus capsids, characterized by large dimeric blade-like spikes exposed on the

571 surface of the VLPs. This finding supports the assertion that prawn nodavirus should be

572 classified into a new genus.

\section{CONCLUSIONS}

576 Prawn nodaviruses are relatively new compared to the typical alpha- and beta-nodaviruses.

577 Despite their genomic and structural differences with the two established genera, prawn 578 nodaviruses have yet been classified into a new genus. There are likely more prawn nodaviruses 579 unknown to men, such as the recently discovered CMNV and FdNV. Isolation and 580 characterization of these new prawn nodaviruses could contribute in creating a new genus of 581 Nodaviridae, which is the gamma-nodavirus. In addition, there is yet an effective mid- or long582 term vaccine for shrimps and prawns against nodavirus infections. Due to the lack of adaptive 583 immune response in crustacean, antigens that can induce protection against the infections have to 584 be administrated from time to time, especially during the larval stage. Therefore, nodavirus 585 vaccines based on recombinant proteins incorporated into feeds would be more relevant. Better 586 yet, self-replicating DNA expression vector-based vaccines would be more cost-effective to be 587 utilized in shrimp and prawn aquaculture industries. 


\section{REFERENCES}

598 Abdul Majeed S, Nambi KS, Taju G, Sahul Hameed AS. 2013. Development, characterization 599 and application of a new fibroblastic-like cell line from kidney of a freshwater air breathing fish 600 Channa striatus (Bloch, 1793). Acta Tropica 127:25-32. doi: 10.1016/j.actatropica.2013.03.013.

601 Arcier JM, Herman F, Lightner DV, Redman RM, Mari J, Bonami JR. 1999. A viral disease 602 associated with mortalities in hatchery-reared postlarvae of the giant freshwater prawn 603 Macrobrachium rosenbergii. Diseases of Aquatic Organisms 38:177-181. doi: 10.1186/s40064$604 \quad 016-3127-z$

605 Sarath Babu V, Abdul Majeed S, Nambi KS, Taju G, Madan N, Sundar Raj N, Sahul Hameed 606 AS. 2013. Comparison of betanodavirus replication efficiency in ten Indian fish cell lines. 607 Archieves of Virology 158:1367-1375. doi: 10.1007/s00705-013-1617-7. 
608 Bajaj S, Banerjee M. 2016. In vitro assembly of polymorphic virus-like particles from the capsid 609 protein of a nodavirus. Virology 496:106-115. doi: 10.1016/j.virol.2016.05.025.

610 Ball LA, Amann JM, Garrett BK. 1992. Replication of nodamura virus after transfection of viral 611 RNA into mammalian cells in culture. Journal of Virology 66:2326-2334.

612 Ball LA, Johnson KL. 1998. Nodaviruses of insects. In: Miller LK, Ball LA, ed. The insect 613 viruses. New York: Plenum Publishing Corporation, 225-267.

614 Banerjee D, Hamod MA, Suresh T, Karunasagar I. 2014. Isolation and characterization of a 615 nodavirus associated with mass mortality in Asian seabass (Lates calcarifer) from the west coast 616 of India. VirusDisease 25:425-429. doi: 10.1007/s13337-014-0226-8.

617 Bashiruddin JB, Cross GF. 1987. Boolarra virus: Ultrastructure of intracytoplasmic virus 618 formation in cultured Drosophila cells. Journal of Invertebrate Pathology 49:303-315. doi: $619 \quad 10.1016 / 0022-2011(87) 90062-0$.

620 Binesh CP, Renuka K, Malaichami N, Greeshma C. 2013. First report of viral nervous necrosis621 induced mass mortality in hatchery-reared larvae of clownfish, Amphiprion sebae Bleeker. 622 Journal of Fish Diseases 36:1017-1020. doi: 10.1111/jfd.12001.

623 Bonami JR, Sri Widada J. 2011. Viral diseases of the giant fresh water prawn Macrobrachium 624 rosenbergii: a review. Journal of Invertebrate Pathology 106:131-142. doi: 625 10.1016/j.jip.2010.09.007.

626 Bovo G, Gustinelli A, Quaglio F, Gobbo F, Panzarin V, Fusaro A, Mutinelli F, Caffara M, 627 Fioravanti M. 2011. Viral encephalopathy and retinopathy outbreak in freshwater fish farmed in 628 Italy. Diseases of Aquatic Organisms 96:45-54. doi: 10.3354/dao02367. 
629 Bravo J, Real F, Padilla D, Olveira JG, Grasso V, Roman L, Acosta F. 2013. Effect of 630 lipopolysaccharides from Vibrio alginolyticus on the Mx gene expression and virus recovery 631 from gilthead seabream (Sparus aurata L.) experimentally infected with Nodavirus. Fish \& 632 Shellfish Immunology 34:383-386. doi: 10.1016/j.fsi.2012.10.012.

633 Breuil G, Bonami JR, Pepin JF, Pichot Y. 1991. Viral infection (picorna-like virus) associated 634 with mass mortalities in hatchery-reared sea-bass (Dicentrarchus labrax) larvae and juveniles. 635 Aquaculture 97:109-116. doi: 10.1016/0044-8486(91)90258-9

636 Breuil G, Pepin JFP, Boscher S, Thiery R. 2002. Experimental vertical transmission of nodavirus 637 from broodfish to eggs and larvae of the seabass, Dicentrarchus labrax (L.). Journal of Fish 638 Diseases 25:697-702. doi: 10.1046/j.1365-2761.2002.00406.x pmid:WOS:000179771900001

639 Buonocore F, Randelli E, Tranfa P, Scapigliati G. 2012. A CD83-like molecule in seabass 640 (Dicentrarchus labrax): Molecular characterization and modulation by viral and bacterial 641 infection. Fish \& Shellfish Immunology 32:1179-1184. doi: 10.1016/j.fsi.2012.02.027.

642 Buonocore F, Stocchi V, Nunez-Ortiz N, Randelli E, Gerdol M, Pallavicini A, Facchiano A, 643 Bernini C, Guerra L, Scapigliati G. 2017. Immunoglobulin T from seabass (Dicentrarchus 644 labrax L.): molecular characterization, tissue localization and expression after nodavirus 645 infection. BMC Molecular Biology 18:8. doi: 10.1186/s12867-017-0085-0.

646 Cai D, Qiu Y, Qi N, Yan R, Lin M, Nie D, Zhang J, Hu Y. 2010. Characterization of Wuhan 647 nodavirus subgenomic RNA3 and the RNAi inhibition property of its encoded protein B2. Virus 648 Research 151:153-161. doi: 10.1016/j.virusres.2010.04.010. 
649 Chaivisuthangkura P, Longyant S, Sithigorngul P. 2014. Immunological-based assays for 650 specific detection of shrimp viruses. World Journal of Virology 3:1-10. doi: 10.5501/wjv.v3.i1.1.

651 Chaves-Pozo E, Guardiola FA, Mesequer J, Esteban MA, Cuesta A. 2012. Nodavirus infection 652 induces a great innate cell-mediated cytotoxic activity in resistant, gilthead seabream, and 653 susceptible, European seabass, teleost fish. Fish \& Shellfish Immunology 33:1159-1166. doi: 654 10.1016/j.fsi.2012.09.002.

655 Chen HY, Liu W, Wu SY, Chiou PP, Li, YH, Chen YC, Lin GH, Lu MW, Wu JL. 2015. RIG-I 656 specifically mediates group II type I IFN activation in nervous necrosis virus infected zebrafish 657 cells. Fish \& Shellfish Immunology 43: 427-435. doi: 10.1016/j.fsi.2015.01.012.

658 Chen Y, Xiong X, Liu X, Li J, Wen Y, Chen Y, Dai Q, Cao Z, Yu W. 2006. Immunoreactivity of $659 \mathrm{HCV} / \mathrm{HBV}$ epitopes displayed in an epitope-presenting system. Molecular Immunology 43:436660 442. doi: 10.1016/j.molimm.2005.03.002.

661 Chen YM, Kuo CE, Chen GR, Kao YT, Zou J, Secombes CJ, Chen TY. 2014. Functional 662 analysis of an orange-spotted grouper (Epinephelus coioides) interferon gene and 663 characterization of its expression in response to nodavirus infection. Developmental and 664 Comparative Immunology 46:117-128. doi: 10.1016/j.dci.2014.04.004.

665 Chen YM, Kuo CE, Wang TY, Shie PS, Wang WC, Huang SL, Tsai TJ, Chen PP, Chen JC, 666 Chen TY. 2010. Cloning of an orange-spotted grouper Epinephelus coioides heat shock protein $66790 \mathrm{AB}$ (HSP90AB) and characterization of its expression in response to nodavirus. Fish \& 668 Shellfish Immunology 28:895-904. doi: 10.1016/j.fsi.2010.02.004. 
669 Chen YM, Wang TY, Chen TY. 2014. Immunity to betanodavirus infections of marine fish. 670 Developmental and Comparative Immunology 43:174-183. doi: 10.1016/j.dci.2013.07.019.

671 Chi S, Hu W, Lo B. 1999. Establishment and characterization of a continuous cell line (GF-1) 672 derived from grouper, Epinephelus coioides (Hamilton): a cell line susceptible to grouper 673 nervous necrosis virus (GNNV). Journal of Fish Diseases 22:173-182. doi: 10.1046/j.1365674 2761.1999.00152.x.

675 Chi SC, Shieh JR, Lin SJ. 2003. Genetic and antigenic analysis of betanodaviruses isolated from 676 aquatic organisms in Taiwan. Diseases of Aquatic Organisms 55:221-228. doi: 677 10.3354/dao055221.

678 Chia TJ, Wu YC, Chen JY, Chi SC. 2010. Antimicrobial peptides (AMP) with antiviral activity 679 against fish nodavirus. Fish \& Shellfish Immunology 28:434-439. doi: 10.1016/j.fsi2009.11.020.

680 Coeurdacier JL, Laporte F, P'epin JF. 2003. Preliminary approach to find synthetic peptides 681 from nodavirus capsid potentially protective against seabass viral encephalopathy and 682 retinopathy. Fish \& Shellfish Immunology 14:435-447. doi: 10.1006/fsim.2002.0449.

683 Comps M, Pepin JF, Bonami JR. 1994. Purification and characterization of two fish encephalitis 684 viruses (FEV) infecting Lates calcarifer and Dicentrarchus labrax. Aquaculture 123:1-10. doi: $685 \quad 10.1016 / 0044-8486(94) 90114-7$.

686 Conceição-Neto N, Zeller M, Heylen E, Lefrère H, Mesquita JR, Matthijnssens J. 2015. Fecal 687 virome analysis of three carnivores reveals a novel nodavirus and multiple gemycircularviruses. 688 Virology Journal 12:79. doi: 10.1186/s12985-015-0305-5. 
689 Costa JZ, Thompson KD. 2016. Understanding the interaction between Betanodavirus and its 690 host for the development of prophylactic measures for viral encephalopathy and retinopathy. 691 Fish \& Shellfish Immunology 53:35-49. doi: 10.1016/j.fsi.2016.03.033.

692 Dearing SC, Scotti PD, Wigley PJ, Dhana SD. 1980. A small RNA virus isolated from the grass 693 grub, Costelytra zealandica (Coleoptera: Scarabaeidae). New Zealand Journal of Zoology 7:267694269.

695 Doan QK, Vandeputte M, Chatain B, Morin T, Allal F. 2017. Viral encephalopathy and 696 retinopathy in aquaculture: a review Journal of Fish Diseases 40:717-742. doi: $697 \quad 10.1111 / \mathrm{jfd} .12541$.

698 Esteban MA, Chaves-Pozo E, Arizcun M, Meseguer J, Cuesta A. 2013. Regulation of natural 699 killer enhancing factor (NKEF) genes in teleost fish, gilthead seabream and European seabass. 700 Molecular Immunology 55:275-282. doi: 10.1016/j.molimm.2013.02.009.

701 Farook MA, Madan N, Taju G, Majeed SA, Nambi KS, Raj NS, Vimal S, Hameed AS. $2014 a$. 702 Production of recombinant capsid protein of Macrobrachium rosenbergii nodavirus (r-MCP43) 703 of giant freshwater prawn, M. rosenbergii (de Man) for immunological diagnostic methods. 704 Journal of Fish Diseases 37:703-710. doi: 10.1111/jfd.12156.

705 Farook M.A., Sundar Raj N., Madan N., Vimal S., Abdul Majeed S., Taju G., Rajkumar T., 706 Santhoshkumar S., Sivakumar S., Sahul Hameed A.S. 2014b. Immunomodulatory effect of 707 recombinant Macrobrachium rosenbergii nodavirus capsid protein (r-MCP) against white tail 708 disease of giant freshwater prawn, Macrobrachium rosenbergii (de Man, 1879). Aquaculture 709 433:395-403. doi: 10.1016/j.aquaculture.2014.07.004. 
710 Fenner BJ, Thiagarajan R, Chua HK, Kwang J. 2006. Betanodavirus B2 is an RNA interference

711 antagonist that facilitates intracelluar viral RNA accumulation. Journal of Virology 80: 85-94.

712 doi: 10.1128/JVI.00296-07.

713 Frerichs G, Rodger HD, Peric Z. 1996. Cell culture isolation of piscine neuropathy nodavirus

714 from juvenile seabass, Dicentrarchus labrax. Journal of General Virology 77:2067-2071. doi:

$715 \quad 10.1099 / 0022-1317-77-9-2067$.

716 Friesen P, Scotti P, Longworth J, Rueckert R. 1980. Black beetle virus: propagation in

717 Drosophila line 1 cells and an infection-resistant subline carrying endogenous black beetle virus-

718 related particles. Journal of Virology 35:741-747.

719 Friesen PD, Rueckert RR. 1982. Black beetle virus: messenger for protein B is a subgenomic 720 viral RNA. Journal of Virology 42:986-995.

721 Ghiasi M, Binaii M, Ghasemi M, Fazli H, Zorriehzahra MJ. 2016. Haemato-biochemical 722 disorders associated with nodavirus like-agent in adult leaping mullet Liza saliens (Risso, 1810) 723 in the Caspian Sea. VirusDisease 27:12-18. doi: 10.1007/s13337-015-0289-1.

724 Goh ZH, Tan SG, Bhassu S, Tan WS. 2011. Virus-like particles of Macrobrachium rosenbergii 725 nodavirus produced in bacteria. Journal of Virological Methods 175:74-79. doi: 726 10.1016/j.jviromet.2011.04.021.

727 Goh ZH, Mohd NA, Tan SG, Bhassu S, Tan WS. 2014. RNA-binding region of Macrobrachium 728 rosenbergii nodavirus capsid protein. Journal of General Virology 95:1919-1928. doi: 729 10.1099/vir.0.064014-0. 
730 Greninger AL, DeRisi JL. 2015. Draft genome sequences of ciliovirus and brinovirus from San

731 Francisco wastewater. Genome Announcements 3:e00651-15. doi: 10.1128/genomeA.00651-15.

732 Guarino LA, Ghosh A, Dasmahapatra B, Dasgupta R, Kaesberg P. 1984. Sequence of the black

733 beetle virus subgenomic RNA and its location in the viral genome. Virology 139:199-203.

734 Hanapi UF, Yong CY, Goh ZH, Alitheen NB, Yeap SK, Tan WS. 2017. Tracking the virus-like 735 particles of Macrobrachium rosenbergii nodavirus in insect cells. PeerJ 5:e2947. doi: $736 \quad 10.7717$ peerj.2947.

737 Hashemi H, Pouyanfard S, Bandehpour M, Noroozbabaei Z, Kazemi B, Saelens X, Mokhtari738 Azad T. 2012. Immunization with M2e-displaying T7 bacteriophage nanoparticles protects 739 against influenza A virus challenge. PLoS One 7:e45765. doi: 10.1371/journal.pone.0045765.

740 Hayakijkosol O, Owens L. 2012. B2 or not B2: RNA interference reduces Macrobrachium 741 rosenbergii nodavirus replication in redclaw crayfish (cherax quadricarinatus). Aquaculture 742 326-329:40-45. doi: 10.1016/j.aquaculture.2011.11.023.

743 Hegde A, Lam TJ, Sin YM. 2005. Immune response of freshwater fish, guppy, Poicelia 744 reticulate and gouramy, Trichogaster trichopterus to recombinant coat protein of Epinephelus 745 tauvina nervous necrosis virus. Aquaculture 249:77-84.

746 Hegde A, Teh HC, Lam TJ, Sin YM. 2003. Nodavirus infection in freshwater ornamental fish, 747 guppy, Poicelia reticulate- comparative characterization and pathogenicity studies. Archives of 748 Virology 148:575-586. doi: 10.1007/s00705-002-0936-x. 
749 Ho KL, Kueh CL, Beh PL, Tan WS, Bhella D. 2017. Cryo-electron microscopy structure of the

750 Macrobrachium rosenbergii nodavirus capsid at 7 Angstroms resolution. Scientific Reports

751 7:2083. doi: 10.1038/s41598-017-02292-0.

752 Hong JR. 2013. Betanodavirus: Mitochondrial disruption and necrotic cell death. World Journal 753 of Virology 2:1-5. doi: 10.5501/wjv.v2.i1.1.

754 Hosur MV, Schmidt T, Tucker RC, Johnson JE, Selling BH, Rueckert RR. 1984. Black beetle 755 virus - crystallization and particle symmetry. Virology 133:119-127.

756 Huang Y, Huang X, Cai J, Wei S, Ouyang Z, Qin Q. 2013. Molecular cloning, expression and 757 functional analysis of ISG15 in orange-spotted grouper, Epinephelus coioides. Fish \& Shellfish 758 Immunology 34:1094-1102. doi: 10.1016/j.fsi.2013.01.010.

759 Huang Y, Yang M, Yu Y, Yang Y, Zhou L, Huang X, Qin Q. 2016a. Grouper TRIM13 exerts 760 negative regulation of antiviral immune response against nodavirus. Fish \& Shellfish 761 Immunology 55:106-115. doi: 10.1016/j.fsi.2016.05.029.

762 Huang Y, Yu Y, Yang Y, Yang M, Zhou L, Huang X, Qin Q. 2016b. Antiviral function of 763 grouper MDA5 against iridovirus and nodavirus. Fish \& Shellfish Immunology 54:188-196. doi: 764 10.1016/j.fsi.2016.04.001.

765 Húsgağ S, Grotmol S, Hjeltnes BK, Rødseth OM, Biering E. 2001. Immune response to a 766 recombinant capsid protein of striped jack nervous necrosis virus (SJNNV) in turbot 767 Scophthalmus maximus and Atlantic halibut Hippoglossus hippoglossus, and evalution of a 768 vaccine against SJNNV. Diseases of Aquatic Organisms 45:33-44. doi: 10.3354/dao045033. 
769 Ibañez LI, Roose K, De Filette M, Schotsaert M, De Sloovere J, Roels S, Pollard C, Schepens B,

770 Grooten J, Fiers W, Saelens X. 2013. M2e-displaying virus-like particles with associated RNA

771 promote $\mathrm{T}$ helper 1 type adaptive immunity against influenza A. PLoS One 8:e59081. doi:

772 10.1371/journal.pone.0059081.

773 Jariyapong P. 2015. Nodavirus-based biological container for targeted delivery system. Artificial

774 Cells, Nanomedicine, and Biotechnology 43:355-360. doi: 10.3109/21691401.2014.889702.

775 Jariyapong P, Chotwiwatthanakun C, Somrit M, Jitrapakdee S, Xing L, Cheng HR,

776 Weerachatyanukul W. 2014. Encapsulation and delivery of plasmid DNA by virus-like

777 nanoparticles engineered from Macrobrachium rosenbergii nodavirus. Virus Research 179:140-

778 146. doi: 10.1016/j.virusres.2013.10.021.

779 Kai YH, Chi SC. 2008. Efficacies of inactivated vaccines against betanodavirus in grouper larvae 780 (Epinephelus coioides) by bath immunization. Vaccine 26:1450-1457. doi: $781 \quad 10.1016 /$ j.vaccine.2007.12.043.

782 Kai YH, Wu YC, Chi SC. 2014. Immune gene expressions in grouper larvae (Epinephelus 783 coioides) induced by bath and oral vaccinations with inactivated betanodavirus. Fish \& Shellfish 784 Immunology 40:563-569. doi: 10.1016/j.fsi.2014.08.005.

785 Keawcharoen J, Techangamsuwan S, Ponpornpisit A, Lombardini ED, Patchimasiri T, Pirarat N. 786 2015. Genetic characterization of a betanodavirus isolated from a clinical disease outbreak in 787 farm-raised tilapia Oreochromis niloticus (L.) in Thailand. Journal of Fish Diseases 38:49-54. 788 doi: $10.1111 /$ jfd.12200. 
789 Kim HJ, Lee JY, Kang HA, Lee Y, Park EJ, Kim HJ. 2013. Oral immunization with whole yeast 790 producing viral capsid antigen provokes a stronger humoral immune response than purified viral 791 capsid antigen. Letters in Applied Microbiology 58:285-291. doi: 10.1111/lam.12188.

792 Kitamura SI, Akizuki M, Song JY, Nakayama K. 2017. Tributyltin exposure increases mortality 793 of nodavirus infected Japanese medaka Oryzias latipes larvae. Marine Pollution Bulletin in press. 794 doi: 10.1016/j.marpolbul.2017.02.020.

795 Kocan RM, Hershberger PK, Elder NE. 2001. Survival of the North American strain of viral 796 hemorrhagic septicemia virus (VHSV) in filtered seawater and seawater containing ovarian fluid, 797 crude oil and serum-enriched culture medium. Diseases of Aquatic 44:75-78. doi: $798 \quad 10.3354 /$ dao044075.

799 Kok WL, Yusoff K, Nathan S, Tan WS. 2002. Cloning, expression and display of the PreS 800 domain of hepatitis B virus on filamentous bacteriophage M13. Journal of Biochemistry, 801 Molecular Biology, and Biophysics 6:55-58. doi: 10.1080/10258140290010241.

802 Kopek BG, Settles EW, Friesen PD, Ahlquist P. 2010. Nodavirus-induced membrane 803 rearrangement in replication complex assembly requires replicase protein a, RNA templates, and 804 polymerase activity. Journal of Virology 84:12492-12503. doi: 10.1128/JVI.01495-10.

805 Kueh CL, Yong CY, Masoomi Dezfooli S, Bhassu S, Tan SG, Tan WS. 2017. Virus-like particle 806 of Macrobrachium rosenbergii nodavirus produced in Spodoptera frugiperda (Sf9) cells is 807 distinctive from that produced in Escherichia coli. Biotechnology Progress 33:549-557. doi: $80810.1002 /$ btpr.2409. 
809 Kuo HC, Wang TY, Hsu HH, Lee SH, Chen YM, Tsai TJ, Ou MC, Ku HT, Lee GB, Chen TY.

810 2012. An automated microfluidic chip system for detection of piscine nodavirus and

811 characterization of its potential carrier in grouper farms. PLoS One 7:e42203. doi:

812 10.1371/journal.pone.0042203.

813 Lawrence S, Reid J, Whalen M. 2015. Secretion of interferon gamma from human immune cells

814 is altered by exposure to tributyltin and dibutyltin. Environmental Toxicology 30:559-571. doi:

815 10.1002/tox.21932.

816 Lin CC, Lin JHY, Chen MS, Yang HL. 2007. An oral nervous necrosis virus vaccine that

817 induces protective immunity in larvae of grouper (Epinephelus coioides). Aquaculture 268:265-

818 273. doi: 10.1016/j.aquaculture.2007.04.066.

819 Lin F, Liu L, Hao GJ, Cao Z, Sheng PC, Wu YL, Shen JY. 2014. Rapid detection of 820 Macrobrachium rosenbergii nodavirus isolated in China by a reverse-transcription loop821 mediated isothermal amplification assay combined with a lateral flow dipstick method. Bing Du 822 Xие Bao 30:502-507.

823 Lingel A, Simon B, Izaurralde E, Sattler M. 2005. The structure of the flock house virus B2 824 protein, a viral suppressor of RNA interference shows a novel mode of double-stranded RNA 825 recognition. EMBO Reports 6:1149-1155. doi: 10.1038/sj.embor.7400583.

826 Liu C, Zhang J, Yi F, Wang J, Wang X, Jiang H, Xu J, Hu Y. 2006a. Isolation and RNA1 827 nucleotide sequence determination of a new insect nodavirus from Pieris rapae larvae in Wuhan 828 city, China. Virus Research 120:28-35. doi: 10.1016/j.virusres.2005.09.003. 
829 Liu W, Hsu CH, Chang CY, Chen HH, Lin CS. 2006b. Immune response against grouper 830 nervous necrosis virus by vaccination of virus-like particles. Vaccine 24:6282-6287. doi: 831 10.1016/j.vaccine.2006.05.073.

832 Lopez-Munoz A, Sepulcre MP, Garcia-Moreno D, Fuentes I, Bejar J, Manchado M, Alvarez MC, 833 Meseguer J, Mulero V. 2012. Viral nervous necrosis virus persistently replicates in the central 834 nervous system of asymptomatic gilthead seabream and promotes a transient inflammatory 835 response followed by the infiltration of $\operatorname{IgM}^{+}$B lymphocytes. Developmental and Comparative 836 Immunology 37:429-437. doi: 10.1016/j.dci.2012.02.007.

837 Low CF, Syarul Nataqain B, Chee HY, Rozaini MZH, Najiah M. 2017. Betanodavirus: 838 dissection of the viral life cycle. Journal of Fish Diseases in press. doi: 10.1111/jfd.12638.

839 Luo YC, Wang CH, Wu YM, Liu W, Lu MW, Lin CS. 2014. Crystallization and X-ray 840 diffraction of virus-like particles from a piscine betanodavirus. Acta Crystallographica Section F 841 Structural Biology and Crystallization Communications 70:1080-1086. doi: $84210.1107 / \mathrm{S} 2053230 X 14013703$.

843 Manayani DJ, Thomas D, Dryden KA, Reddy V, Siladi ME, Marlett JM, Rainey GJ, Pique ME, 844 Scobie HM, Yeager M, Young JA, Manchester M, Schneemann A. 2007. A viral nanoparticle 845 with dual function as an anthrax antitoxin and vaccine. PLoS Pathogens 3:1422-1431. doi: 846 10.1371/journal.ppat.0030142.

847 Matic S, Rinaldi R, Masenga V, Noris E. 2011. Efficient production of chimeric human 848 papillomavirus $16 \mathrm{~L} 1$ protein bearing the M2e influenza epitope in Nicotiana benthamiana plants. 849 BMC Biotechnology 11:106. doi: 10.1186/1472-6750-11-106. 
850 Miller DJ, Schwartz MD, Ahlquist P. 2001. Flock house virus RNA replicates on outer

851 mitochondrial membranes in Drosophila cells. Journal of Virology 75:11664-11676. doi:

852 10.1128/JVI.75.23.11664-11676.2001.

853 Mori K, Nakai T, Muroga K, Arimoto M, Mushiake K, Furusawa I. 1992. Properties of a new

854 virus belonging to Nodaviridae found in larval striped jack (Pseudocaranx dentex) with nervous

855 necrosis. Virology 187:368-371. doi: 10.1016/0042-6822(92)90329-N.

856 Munday BL, Kwang J, Moody N. 2002. Betanodavirus infections of teleost fish: a review.

857 Journal of Fish Diseases 25:127-142. doi: 10.1046/j.1365-2761.2002.00350.x.

858 Munday BL, Nakai T. 1997. Special topic review: nodaviruses as pathogens in larval and 859 juvenile marine finfish. World Journal of Microbiology and Biotechnology 13:375-381. doi: $86010.1023 / \mathrm{A}: 1018516014782$.

861 Murata K, Lechmann M, Qiao M, Gunji T, Alter HJ, Liang TJ. 2003. Immunization with 862 hepatitis $\mathrm{C}$ virus-like particles protects mice from recombinant hepatitis $\mathrm{C}$ virus-vaccinia 863 infection. Proceedings of the National Academy of Sciences of the United States of America 864 100:6753-6758. doi: 10.1073/pnas.1131929100.

865 Murray K, Shiau AL. 1999. The core antigen of hepatitis B virus as a carrier for immunogenic 866 peptides. Biological Chemistry 380:277-283. doi: 10.1515/BC.1999.038.

867 Murwantoko M, Bimantara A, Roosmanto R, Kawaichi M. 2016. Macrobrachium rosenbergii 868 nodavirus infection in a giant freshwater prawn hatchery in Indonesia. SpringerPlus 5:1729. doi: 869 10.1186/s40064-016-3127-z. 
870 Naveen Kumar S, Karunasagar I, Karunasagar I. 2013. Protection of Macrobrachium rosenbergii

871 against white tail disease by oral administration of bacterial expressed and encapsulated double-

872 stranded RNA. Fish \& Shellfish Immunology 35:833-839. doi: 10.1016/j.fsi.2013.06.019.

873 NaveenKumar S, Shekar M, Karunasagar I, Karunasagar I. 2013. Genetic analysis of RNA1 and 874 RNA2 of Macrobrachium rosenbergii nodavirus $(M r \mathrm{NV})$ isolated from India. Virus Research 875 173:377-385. doi: 10.1016/j.virusres.2013.01.003.

$876 \mathrm{Ng}$ TFF, Alvandi S, Varsani A, Burghart S, Breitbart M. 2013. Metagenomic identification of a 877 nodavirus and a circular ssDNA virus in semi-purified viral nucleic acids from the 878 hepatopancreas of healthy Farfantepenaeus duorarum shrimp. Diseases of Aquatic Organisms 879 105:237-242. doi: 10.3354/dao02628.

880 Nishi S, Yamashita H, Kawato Y, Nakai T. 2016. Cell culture isolation of piscine nodavirus 881 (betanodavirus) in fish-rearing seawater. Applied and Environmental Microbiology 82:2537882 2544. doi: 10.1128/AEM.03834-15.

883 Nishizawa T, Mori K, Nakai T, Furusawa I, Muroga K. 1994. Polymerase chain reaction (PCR) 884 amplification of RNA of striped jack nervous necrosis virus (SJNNV). Disease of Aquatic 885 Organisms 18:103-107.

886 Ourth DD, Renis HE. 1993. Antiviral melanization reaction of Heliothis virescens hemolymph 887 against DNA and RNA viruses in vitro. Comparative Biochemistry and Physiology Part B 888 105:719-723. 
889 Overgård AC, Nerland AH, Fiksdal IU, Patel S. 2012. Atlantic halibut experimentally infected 890 with nodavirus shows increased levels of T-cell marker and IFN $\gamma$ transcripts. Developmental and 891 Compartive Immunology 37:139-150. doi: 10.1016/j.dci.2011.10.003.

892 Pakingking Jr R, Mori KI, Sugaya T, Oka M, Okinaka Y, Nakai T. 2005. Aquabirnavirus893 induced protection of marine fish against piscine nodavirus infection. Fish Pathology 40:125-131. 894 doi: 10.3147 jsfp.40.125.

895 Pakingking Jr R, Seron R, dela Peña L, Mori K, Yamashita H, Nakai T. 2009. Immune responses 896 of Asian seabass, Lates calcarifer Bloch, against an inactivated betanodavirus vaccine. Journal 897 of Fish Diseases 32:457-463. doi: 10.1111/j.1365-2761.2009.01040.x.

898 Pakingking Jr R., Bautista NB, Jesus-Ayson EG, Reyes O. 2010. Protective immunity against 899 viral nervous necrosis (VNN) in brown-marbled grouper (Epinephelus fuscogutattus) following 900 vaccination with inactivated betanodavirus. Fish \& Shellfish Immunology 28:525-533. doi: $901 \quad$ 10.1016/j.fsi.2009.12.004.

902 Parameswaran V, Kumar SR, Ahmed VPI, Sahul Hameed AS. 2008. A fish nodavirus associated 903 with mass mortality in hatchery-reared Asian Seabass, Lates calcarifer. Aquaculture 275:366904 369. doi: 10.1016/j.aquaculture.2008.01.023.

905 Peng M, Dai CB, Chen YD. 2005. Expression and immunoreactivity of an epitope of HCV in a 906 foreign epitope presenting system. World Journal of Gastroenterology 11:3363-3367. doi: 907 10.3748/wjg.v11.i22.3363.

908 Piazzon MC, Galindo-Villegas J, Pereiro P, Estensoro I, Calduch-Giner JA, Gomez-Casado E, 909 Novoa B, Mulero V, Sitja-Bobadilla A, Perez-Sanchez J. 2016. Differential modulation of IgT 
910 and IgM upon parasitic, bacterial, viral, and dietary challenges in a perciform fish. Frontiers in

911 Immunology 7:637. doi: 10.3389/fimmu.2016.00637.

912 Poisa-Beiro L, Dios S, Montes A, Aranguren R, Figueras A, Novoa B. 2008. Nodavirus

913 increases the expression of Mx and inflammatory cytokines in fish brain. Molecular Immunology

914 45:218-225. doi: 10.1016/j.molimm.2007.04.016.

915 Popham HJ, Shelby KS, Brandt SL, Coudron TA. 2004. Potent virucidal activity in larval

916 Heliothis virescens plasma against Helicoverpa zea single capsid nucleopolyhedrovirus. Journal

917 of General Virology 85:2255-2261. doi: 10.1099/vir.0.79965-0.

918 Price BD, Rueckert RR, Ahlquist P. 1996. Complete replication of an animal virus and 919 maintenance of expression vectors derived from it in Saccharomyces cerevisiae. Proceedings of 920 the National Academy of Sciences of the United States of America 93:9465-9470.

921 Qian D, Shi Z, Zhang S, Cao Z, Liu W, Li L, Xie Y, Cambournac I, Bonami JR. 2003. Extra 922 small virus-like particles (XSV) and nodavirus associated with whitish muscle disease in the 923 giant freshwater prawn, Macrobrachium rosenbergii. Journal of Fish Diseases 26:521-527. doi: 924 10.1046/j.1365-2761.2003.00486.x.

925 Quan FS, Compans RW, Nguyen HH, Kang SM. 2008. Induction of heterosubtypic immunity to 926 influenza virus by intranasal immunization. Journal of Virology 82:1350-1359. doi: 927 10.1128/JVI.01615-07.

928 Ramya VL, Sharma R, Gireesh-Babu P, Patchala SR, Rather A, Nandanpawar PC, Eswaran S. 929 2014. Development of chitosan conjugated DNA vaccine against nodavirus in Macrobrachium 930 rosenbergii (De Man, 1879). Journal of Fish Diseases 37:815-824. doi: 10.1111/jfd.12179. 
931 Ravi M, Nazeer Basha A, Taju G, Ram Kumar R, Sahul Hameed AS. 2010. Clearance of

932 Macrobrachium rosenbergii nodavirus (MrNV) and extra small virus (XSV) and immunological

933 changes in experimentally injected Macrobrachium rosenbergii. Fish \& Shellfish Immunology

934 28:428-433. doi: 10.1016/j.fsi.2009.11.022.

935 Ravi M, Nazeer Basha A, Sarathi M, Rosa Idalia HH, Sri Widada J, Bonami JR, Sahul Hameed

936 AS. 2009. Studies on the occurrence of white tail disease (WTD) caused by $M r N V$ and XSV in

937 hatchery-reared post-larvae of Penaeus indicus and P. monodon. Aquaculture 292:117-120. doi:

938 10.1016/j.aquaculture.2009.03.051.

939 Reinganum C, Bashiruddin JB, Cross GF. 1985. Boolarra virus: a member of the Nodaviridae 940 isolated from Oncopera intricoides (Lepidoptera: Hepialidae). Intervirology 24:10-17.

941 Reshi ML, Su YC, Hong JR. 2014. RNA Viruses: ROS-Mediated Cell Death. International 942 Journal of Cell Biology 2014:467452. doi: 10.1155/2014/467452.

943 Sadler AJ, Williams BRG. 2008. Interferon-inducible antiviral effectors. Nature Reviews 944 Immunology 8:559-568. doi: 10.1038/nri2314.

945 Sahul Hameed AS, Yoganandhan K, Sri Widada J, Bonami JR. 2004. Experimental transmission 946 and tissue tropism of Macrobrachium rosenbergii nodavirus (MrNV) and its associated extra 947 small virus (XSV). Diseases of Aquatic Organisms 62:191-196. doi: 10.3354/dao062191.

948 Scapigliati G, Buonocore F, Fandelli E, Casani D, Meloni S, Zarletti G, Tiberi M, Pietretti D, 949 Boschi I, Manchado M, Martin-Antonio B, Jimenez-Cantizano R, Bobo G, Borghesan F, 950 Lorenzen N, Einer-Jensen K, Adams S, Thompson K, Alonso C, Bejar J, Cano I, Borrego JJ, 951 Alvarez MC. 2010. Cellular and molecular immune responses of the sea bass (Dicentrarchus 
952 labrax) experimentally infected with betanodavirus. Fish \& Shellfish Immunology 28:303-311.

953 doi: 10.1016/j.fsi.2009.11.008.

954 Schuster S, Zirkel F, Kurth A, Cleef KWR, Drosten C, Rij RP, Junglen S. 2014. A unique

955 nodavirus with novel features: Mosinovirus expresses two subgenomic RNAs, a capsid gene of

956 unknown origin, and a suppressor of the antiviral RNA interference pathway. Journal of

957 Virology 88:13447-13459. doi: 10.1128/JVI.02144-14.

958 Selling BH, Allison RF, Kaesberg P. 1990. Genomic RNA of an insect virus directs synthesis of 959 infectious virions in plants. Proceedings of the National Academy of Sciences of the United 960 States of America 87:434-438.

961 Selling BH, Rueckert RR. 1984. Plaque assay for black beetle virus. Journal of Virology 51:251962253.

963 Senapin S, Jaengsanong C, Phiwsaiya K, Prasertsri S, Laisutisan K, Chuchird N, Limsuwan C, 964 Flegel TW. 2012. Infections of MrNV (Macrobrachium rosenbergii nodavirus) in cultivated 965 whiteleg shrimp Penaeus vannamei in Asia. Aquaculture 338-341:41-46. doi: 966 10.1016/j.aquaculture.2012.01.019.

967 Settles EW, Friesen PD. 2008. Flock house virus induces apoptosis by depletion of Drosophila 968 inhibitor-of-apoptosis protein DIAP1. Journal of Virology 82:1378-1388. 969 doi:10.1128/JVI.01941-07.

970 Skliris GP, Krondiris JV, Sideris DC, Shinn AP, Starkey WG, Richard RH. 2001. Phylogenetic 971 and antigenic characterization of new fish nodavirus isolates from Europe and Asia. Virus 972 Research 75:59-67. doi: 10.1016/S0168-1702(01)00225-8. 
973 Sommerset I, Lorenzen E, Lorenzen N, Bleie H. 2003. A DNA vaccine directed against a

974 rainbow trout rhabdovirus induces early protection against a nodavirus challenge in turbot.

975 Vaccine 21:4661-4667. doi: 10.1016/S0264-410X(03)00526-7.

976 Sommerset I, Skern R, Biering E, Bleie H, Fiksdal I, Grove S, Nerland AH. 2005. Protection

977 against Atlantic halibut nodavirus in turbot is induced by recombinant capsid protein vaccination 978 but not following DNA vaccination. Fish \& Shellfish Immunology 18:13-29. doi: $979 \quad$ 10.1016/j.fsi.2004.03.006.

980 Somrit M, Watthammawut A, Chotwiwatthanakun C, Ounjai P, Suntimanawong W, 981 Weerachatyanukul W. 2017. C-terminal domain on the outer surface of the Macrobrachium 982 rosenbergii nodavirus capsid is required for $\mathrm{Sf9}$ cell binding and internalization. Virus Research 983 227:41-48. doi: 10.1016/j.virusres.2016.09.017.

984 Sri Widada J, Durand S, Cambournac I, Qian D, Shi Z, Dejonghe E, Richard V, Bonami JR. 985 2003. Genome-based detection methods of Macrobrachium rosenbergii nodavirus, a pathogen of 986 the giant freshwater prawn, Macrobrachium rosenbergii dot-blot, in situ hybridization and RT987 PCR. Journal of Fish Diseases 26:583-590. doi: 10.1046/j.1365-2761.2003.00493.x.

988 Sudhakaran R, Ishaq Ahmed VP, Haribabu P, Mukherjee SC, Sri Widada J, Bonami JR, Sahul 989 Hameed AS. 2007. Experimental vertical transmission of Macrobrachium rosenbergii nodavirus $990(\mathrm{MrNV})$ and extra small virus (XSV) from brooders to progeny in Macrobrachium rosenbergii 991 and artemia. Journal of Fish Diseases 30:27-35. doi: 10.1111/j.1365-2761.2007.00774.x.

992 Suebsing R, Prombun P, Kiatpathomchai W. 2013. Reverse transcription loop-mediated 993 isothermal amplification (RT-LAMP) combined with colorimetric gold nanoparticle (AuNP) 
994 probe assay for visual detection of Penaeus vannamei nodavirus (PvNV). Letters in Applied 995 Microbiology 56:428-435. doi: 10.1111/lam.12065.

996 Takano T, Kondo H, Hirono I, Endo M, Saito-Taki T, Aoki T. 2011. Toll like receptors in 997 teleosts, in: M.G.Bondad-Reantaso, Jones JB, Corsin F, Aoki T (Eds.), Diseases in Asian 998 Aquaculture VII. Selangor, Malaysia. Fish Health Section, Asian Fisheries Society, 2011:197999207.

1000 Tan GH, Yusoff K, Seow HF, Tan WS. 2005. Antigenicity and immunogenicity of the 1001 immunodominant region of hepatitis B surface antigen displayed on bacteriophage T7. Journal 1002 of Medical Virology 77:475-480. doi: 10.1002/jmv.20479.

1003 Tang KF, Pantoja CR, Redman RM, Lightner DV. 2007. Development of in situ hybridization 1004 and RT-PCR assay for the detection of a nodavirus (PvNV) that causes muscle necrosis in 1005 Penaeus vannamei. Diseases of Aquatic Organisms 75:183-190. doi: 10.3354/dao075183.

1006 Tang KF, Pantoja CR, Redman RM, Navarro SA, Lightner DV. 2011. Ultrastructural and 1007 sequence characterization of Penaeus vannamei nodavirus (PvNV) from Belize. Diseases of 1008 Aquatic Organisms 94:179-187. doi: 10.3354/dao02335.

1009 Thiery R, Cozien J, Cabon J, Lamour F, Baud M, Schneemann A. 2006. Induction of a protective 1010 immune response against viral nervous necrosis in the European seabass Dicentrarchus labrax 1011 by using betanodavirus virus-like particles. Journal of Virology 80:10201-10207. doi: $1012 \quad 10.1128 /$ JVI.01098-06. 
1013 Toubanaki DK, Margaroni M, Karagouni E. 2015a. Development of a Novel Allele-Specific

1014 PCR Method for Rapid Assessment of Nervous Necrosis Virus Genotypes. Current 1015 Microbiology 71:529-539. doi: 10.1007/s00284-015-0880-0.

1016 Toubanaki DK, Margaroni M, Karagouni E. 2015b. Nanoparticle-based lateral flow biosensor 1017 for visual detection of fish nervous necrosis virus amplification products. Molecular and 1018 Cellular Probes 29:158-166. doi: 10.1016/j.mcp.2015.03.005.

1019 Valero Y, Arizcun M, Esteban MA, Bandin I, Olveira JG, Patel S, Cuesta A, Chaves-Pozo E. 1020 2015a. Nodavirus colonizes and replicates in the testis of gilthead seabream and European 1021 seabass modulating its immune and reproductive functions. PLoS One 10:e0145131. doi: 1022 10.1371/journal.pone.0145131.

1023 Valero Y, Arizcun M, Esteban MA, Cuesta A, Chaves-Pozo E. 2016a. Transcription of histones $1024 \mathrm{H} 1$ and H2B in regulated by several immune stimuli in gilthead seabream and European seabass. 1025 Fish \& Shellfish Immunology 57:107-115. doi: 10.1016/j.fsi.2016.08.019.

1026 Valero Y, Awad E, Buonocore F, Arizcun M, Esteban MA, Meseguer J, Chaves-Pozo E, Cuesta 1027 A. 2016b. An oral chitosan DNA vaccine against nodavirus improves transcription of cell1028 mediated cytotoxicity and interferon genes in the European seabass juveniles gut and survival 1029 upon infection. Developmental and Comparative Immunology 65:64-72. doi: $1030 \quad 10.1016 /$ j.dci.2016.06.021.

1031 Valero Y, Garcia-Alcazar A, Esteban MA, Cuesta A, Chaves-Pozo E. 2015b. Antimicrobial 1032 reponse is increased in the testis of European seabass, but not in gilthead seabream, upon 1033 nodavirus infection. Fish \& Shellfish Immunology 44:203-213. doi: 10.1016/j.fsi.2015.02.015. 
1034 Venter PA, Schneemann A. 2008. Recent insights into the biology and biomedical applications

1035 of Flock House virus. Cellular and Molecular Life Sciences 65:2675-2687. doi: 10.1007/s000181036 008-8037-y.

1037 Vimal S, Farook MA, Madan N, Abdul Majeed S, Nambi KSN, Taju G, Sundar raj N, Venu S, 1038 Subburaj R, Thirunavukkarasu AR, Sahul Hameed AS. 2016. Development, distribution and 1039 expression of a DNA vaccine against nodavirus in Asian Seabass, Lates calcarifier (Bloch, 1040 1790). Aquaculture Research 47:1209-1220. doi: 10.1111/are.12578.

1041 Vimal S, Madan, Farook MA, Nambi KSN, Majeed SA, Rajkumar T, Venu S, Thirunavukkarasu 1042 AR, Hameed ASS. 2014. Production of recombinant vaccine using capsid gene of nodavirus to 1043 protect Asian seabass, Lates calcarifer (Bloch, 1790). Aquaculture 418-419:148-154. doi: 1044 10.1016/j.aquaculture.2013.10.017.

1045 Wan Y, Wu Y, Bian J, Wang XZ, Zhou W, Jia ZC, Tan Y, Zhou L. 2001. Induction of hepatitis 1046 B virus-specific cytotoxic T lymphocytes response in vivo by filamentous phage display vaccine. 1047 Vaccine 19:2918-2923. doi: 10.1016/S0264-410X(00)00561-2.

1048 Wang CS, Chang CY, Wen CM. 2016. Developing immunological methods for detecting 1049 Macrobrachium rosenbergii nodavirus and extra small virus using a recombinant protein 1050 preparation. Journal of Fish Diseases 39:715-727. doi: 10.1111/jfd.12404.

1051 Wang TY, Chen YM, Chen TY. 2016. Molecular cloning of orange-spotted grouper 1052 (Epinephelus coioides) heat shock transcription factor 1 isoforms and characterization of their 1053 expressions in response to nodavirus. Fish \& Shellfish Immunology 59:123-136. doi: 1054 10.1016/j.fsi.2016.10.032. 
1055 Wang W, Huang Y, Yu Y, Yang Y, Xu X, Chen X, Ni S, Qin Q, Huang X. 2016. Fish TRIM39

1056 regulates cell cycle progression and exerts its antiviral function against iridovirus and nodavirus.

1057 Fish \& Shellfish Immunology 50:1-10. doi: 10.1016/j.fsi.2016.01.016.

1058 Wangman P, Senapin S, Chaivisuthangkura P, Longyant S, Rukpratanporn S, Sithigorngul P. 1059 2012. Production of monoclonal antibodies specific to Macrobrachium rosenbergii nodavirus 1060 using recombinant capsid protein. Diseases of Aquatic Organisms 98:121-31. doi: 1061 10.3354/dao02431.

1062 Xie H, Wei J, Qin Q. 2016. Antiviral function of Tachyplesin I against iridovirus and nodavirus. 1063 Fish \& Shellfish Immunology 58:96-102. doi: 10.1016/j.fsi.2016.09.015.

1064 Yang Y, Huang Y, Yu Y, Yang M, Zhou S, Qin Q, Huang X. 2016. RING domain is essential 1065 for the antiviral activity of TRIM25 from orange spotted grouper. Fish \& Shellfish Immunology 1066 55:304-314. doi: 10.1016/j.fsi.2016.06.005.

1067 Yap WB, Tey BT, Alitheen NB, Tan WS. 2012. Display of the antigenic region of Nipah virus 1068 nucleocapsid protein on hepatitis B virus capsid. Journal of Bioscience and Bioengineering 1069 113:26-29. doi: 10.1016/j.jbiosc.2011.09.007.

1070 Yong CY, Yeap SK, Goh ZH, Ho KL, Omar AR, Tan WS. 2015a. Induction of humoral and cell1071 mediated immune responses by hepatitis B virus epitope displayed on the virus-like particles of 1072 prawn nodavirus. Applied and Environmental Microbiology 81:882-889. doi: 1073 10.1128/AEM.03695-14. 
1074 Yong CY, Yeap SK, Ho KL, Omar AR, Tan WS. 2015b. Potential recombinant vaccine against 1075 influenza A virus based on M2e displayed on nodaviral capsid nanoparticles. International 1076 Journal of Nanomedicine 10:2751-2763. doi: 10.2147/IJN.S77405.

1077 Yoshikoshi K, Inoue K. 1990. Viral nervous necrosis in hatchery-reared larvae and juveniles of 1078 Japanese parrotfish, Oplegathus fasciatus (Temminck \& Schlegel). Journal of Fish Diseases 1079 13:69-77. doi: 10.1111/j.1365-2761.1990.tb00758.x.

1080 Yu Y, Huang X, Liu J, Zhang J, Hu Y, Yang Y, Huang Y, Qin Q. 2017. Fish TRIM32 functions 1081 as a critical antiviral molecule against iridovirus and nodavirus. Fish \& Shellfish Immunology 1082 60:33-43. doi: 10.1016/j.fsi.2016.11.036.

1083 Yu Y, Huang Y, Yang Y, Wang S, Yang M, Huang X, Qin Q. 2016. Negative regulation of the 1084 antiviral response by grouper LGP2 against fish viruses. Fish \& Shellfish Immunology 56:3581085 366. doi: 10.1016/j.fsi.2016.07.015.

1086 Yuasa K, Koesharyani I, Roza D, Mori K, Katata M, Nakai T. 2002. Immune response of 1087 humpback grouper, Cromileptes altivelis (Valenciennes) injected with the recombinant coat 1088 protein of betanodavirus. Journal of Fish Diseases 25:53-56. doi: 10.1046/j.13651089 2761.2002.00325.x.

1090 Zhang Q, Liu Q, Liu S, Yang H, Liu S, Zhu L, Yang B, Jin J, Ding L, Wang X, Liang Y, Wang 1091 Q, Huang J. 2014. A new nodavirus is associated with covert mortality disease of shrimp. 1092 Journal of General Virology 95:2700-2709. doi: 10.1099/vir.0.070078-0. 
1093 Zhang Q, Liu S, Li J, Tian Y, Wang C, Li X, Xu T, Li J. 2017. Experimental vertical 1094 transmission of covert mortality nodavirus (CMNV) in Exopalaemon carinicauda. Journal of 1095 General Virology in press. doi: 10.1099/jgv.0.000731.

1096 Zhang Q, Liu S, Yang H, Zhu L, Wan X, Li X, Huang J. 2015. Reverse transcription loop1097 mediated isothermal amplification for rapid and quantitative assay of covert mortality nodavirus 1098 in shrimp. Journal of Invertebrate Pathology in press. doi: 10.1016/j.jip.2015.09.001.

1099 Zorriehzahra MJ, Nazari A, Ghasemi M, Ghiasi M, Karsidani SH, Bovo G, Daud HHM. 2014. 1100 Vacuolating encephalopathy and retinopathy associated with a nodavirus-like agent: a probable 1101 cause of mass mortality of wild Golden grey mullet (Liza aurata) and Sharpnose grey mullet 1102 (Liza saliens) in Iranian waters of the Caspian Sea. VirusDisease 25:430-436. doi: 1103 10.1007/s13337-014-0238-4. 


\section{Figure Legends}

Figure 1:

Innate antiviral immunity of fish against nodavirus infection. (A) Positive regulation which inhibits viral replication. TRIM25, TRIM32 and TRIM39 upregulate the expression of MDA5, which in turn induces ISRE, IRF3 and IRF7. The upregulation of ISRE also induces the expression of ISG15 and proinflammatory cytokines, cooperatively reducing the viral load.

1123 Other elements known to inhibit virus replication include HSP90, 2-C Type I IFN and

1124 Tachyplesin I, which downregulates HSF1, upregulates Mx promoter and IFN- $\beta$, respectively. 1125 (B) Negative regulation which promotes viral replication. TRIM13 and LGP2 downregulate 1126 MDA5, thereby reduce the ISRE. LGP2 also downregulates Mx promoter, proinflammatory 1127 cytokines and Type I IFN. TRIM: Tripartite motif-containing protein; MDA5: Melanoma 1128 differentiation-associated gene 5; IRF: Interferon regulatory factor; ISRE: Interferon-stimulated 1129 response element; HSF1: Heat shock transcription factor 1; HSP90: Heat shock protein 90; ISG: 1130 Interferon-stimulated gene. 


\section{Figure 1}

Innate antiviral immunity of fish against nodavirus infection.

(A) Positive regulation which inhibits viral replication. TRIM25, TRIM32 and TRIM39 upregulate the expression of MDA5, which in turn induces ISRE, IRF3 and IRF7. The upregulation of ISRE also induces the expression of ISG15 and proinflammatory cytokines, cooperatively reducing the viral load. Other elements known to inhibit virus replication include HSP90, 2-C Type I IFN and Tachyplesin I, which downregulates HSF1, upregulates Mx promoter and IFN- $\beta$, respectively. (B) Negative regulation which promotes viral replication. TRIM13 and LGP2 downregulates MDA5, thereby reduce the ISRE. LGP2 also downregulates Mx promoter, proinflammatory cytokines and Type I IFN. TRIM: Tripartite motif-containing protein; MDA5:

Melanoma differentiation-associated gene 5; IRF: Interferon regulatory factor; ISRE: Interferon-stimulated response element; HSF1: Heat shock transcription factor 1; HSP90: Heat shock protein 90; ISG: Interferonstimulated gene.

\section{A Positive regulation (Viral load $\downarrow$ )}

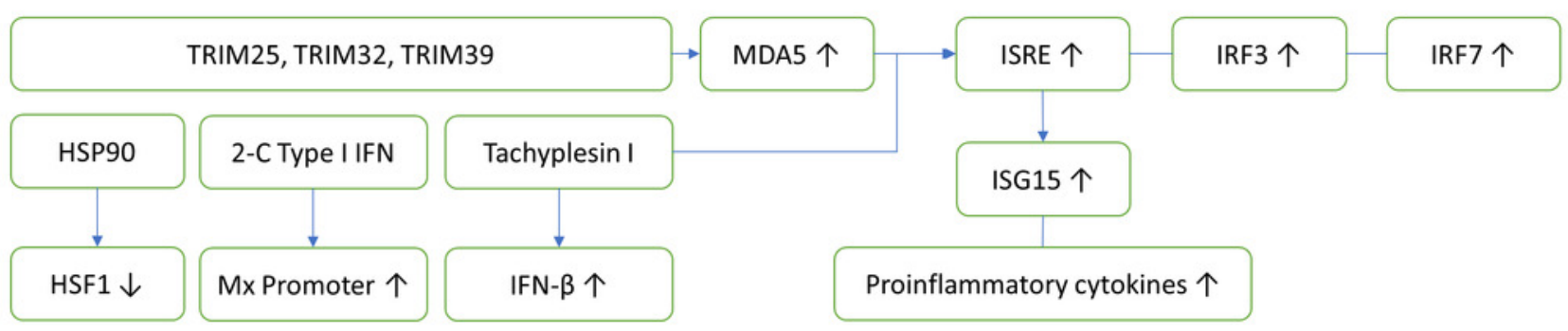

\section{B Negative regulation (Viral load $\uparrow$ )}

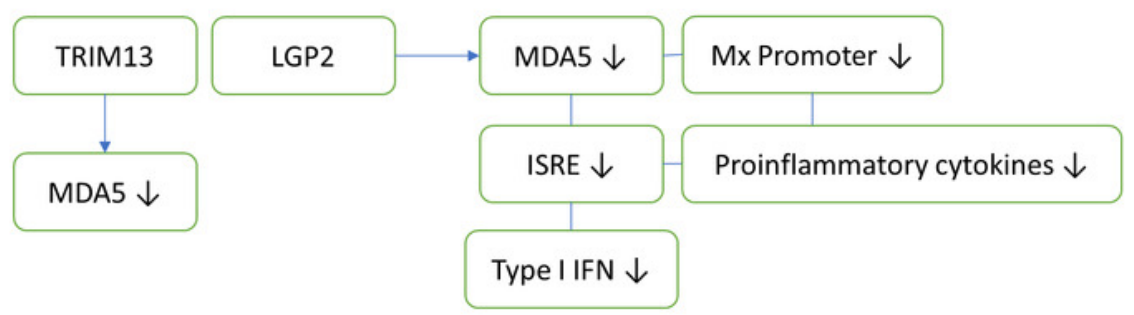




\section{Table $\mathbf{1}$ (on next page)}

Vaccines, route of administration and their protectivity. 


\begin{tabular}{|c|c|c|c|c|}
\hline Type of vaccine & $\begin{array}{l}\text { Route of } \\
\text { vaccination }\end{array}$ & Protectivity & Remarks & References \\
\hline $\begin{array}{l}\text { Recombinant } \\
\text { betanodavirus of } \\
\text { RNA2 capsid protein r- } \\
\text { FNCP42 }\end{array}$ & IM & $\begin{array}{l}75 \% \text { higher survival rate of } \\
\text { juveniles of Asian seabass } \\
\text { challenged with } 1 \times 10^{6.5} \\
\text { TCID }_{50} \text { of nodavirus/fish }\end{array}$ & $\begin{array}{l}\text { As the genome sequence analysis of r-FNCP42 has } \\
\text { more than } 98-99 \% \text { of similarity with other fish } \\
\text { nodavirus including red spotted grouper nervous } \\
\text { necrosis virus, Dicentrarchus labrax encephalitis virus, } \\
\text { Asian seabass nervous necrosis virus, and Epinephelus } \\
\text { tauvina nervous necrosis virus (ETNV), thus cross } \\
\text { protectivity of r-FNCP42 against other strains of } \\
\text { nodavirus shall be tested. }\end{array}$ & $\begin{array}{l}\text { Vimal et al. } \\
(2014 ; 2016)\end{array}$ \\
\hline $\begin{array}{l}\text { Recombinant r- } \\
\text { FNCP42-DNA }\end{array}$ & IM & $\begin{array}{l}77 \% \text { higher survival rate of } \\
\text { juveniles of Asian seabass } \\
\text { challenged with } 1 \times 10^{6.5} \\
\text { TCID }_{50} \text { of nodavirus/fish }\end{array}$ & $\begin{array}{l}\text { Capsid protein was highly expressed in the heart, } \\
\text { muscle and liver of the vaccinated fish. }\end{array}$ & $\begin{array}{l}\text { Vimal et al. } \\
(2016)\end{array}$ \\
\hline $\begin{array}{l}\text { Recombinant capsid } \\
\text { protein MGNNV virus } \\
\text { like particles (VLPs) }\end{array}$ & $\mathrm{IM}$ & $\begin{array}{l}\sim 70 \% \text { higher survival rate of } \\
\text { juvenile European seabass } \\
\text { (Dicentrarchus labrax) } \\
\text { challenged with } 10^{5} \\
\text { TCID }_{50} \text { /fish }\end{array}$ & $\begin{array}{l}\text { MGNNV induced humoral immunity against } \\
\text { nodavirus. }\end{array}$ & $\begin{array}{l}\text { Thiery et al. } \\
(2006)\end{array}$ \\
\hline $\begin{array}{l}\text { DNA vaccine pVHSV- } \\
\text { G encoding } \\
\text { glycoprotein of Viral } \\
\text { hemorrhagic } \\
\text { septicaemia virus }\end{array}$ & IM & $\begin{array}{l}\sim 54 \% \text { higher survival rate of } \\
\text { juvenile turbot (Scophthalmus } \\
\text { maximus) challenged with } \\
10^{6.3} \text { TCID }_{50}\end{array}$ & $\begin{array}{l}\text { DNA vaccine induced inflammatory response that } \\
\text { cross protect nodavirus infection. }\end{array}$ & $\begin{array}{l}\text { Sommerset et } \\
\text { al. }(2003)\end{array}$ \\
\hline $\begin{array}{l}\text { Synthetic peptides }(\mathrm{N}- \\
\text { terminal regions) of }\end{array}$ & $\mathrm{IM}$ & $\begin{array}{l}\sim 27 \% \text { higher survival rate of } \\
\text { seabass challenged with } 10^{9}\end{array}$ & Peptides induced humoral immunity & $\begin{array}{l}\text { Coeurdacier, } \\
\text { Laporte \& }\end{array}$ \\
\hline
\end{tabular}




\begin{tabular}{|c|c|c|c|c|}
\hline $\begin{array}{l}\text { nodavirus DIEV RNA2 } \\
\text { protein }\end{array}$ & & FCU/fish & & $P^{\prime}$ epin (2003) \\
\hline $\begin{array}{l}\text { Heat inactivated } \mathrm{S} 1 \text { and } \\
\mathrm{Sb} 2 \text { nodavirus }\end{array}$ & $\mathrm{IM}$ & $\begin{array}{l}\sim 33 \% \text { and } 26 \% \text { higher } \\
\text { survival rate of seabass } \\
\text { challenged with } 9 \times 10^{9} \\
\text { FCU/fish, respectively }\end{array}$ & Induced humoral immunity & $\begin{array}{l}\text { Coeurdacier, } \\
\text { Laporte \& } \\
\text { P'epin (2003) }\end{array}$ \\
\hline $\begin{array}{l}\text { Virus-like particles } \\
\text { (VLPs) of grouper } \\
\text { nervous necrosis virus }\end{array}$ & $\mathrm{IM}$ & - & $\begin{array}{l}\text { Induced humoral immunity. No challenge test was } \\
\text { performed. }\end{array}$ & $\begin{array}{l}\text { Liu et al. } \\
(2006 b)\end{array}$ \\
\hline $\begin{array}{l}\text { Recombinant RGNNV- } \\
\mathrm{CP}\end{array}$ & $\mathrm{IM}$ & $\begin{array}{l}\sim 60 \% \text { higher survival rate of } \\
\text { humpback grouper challenged } \\
\text { with } 10^{5.5} \mathrm{TCID}_{50} / \text { fish, } \\
\text { respectively }\end{array}$ & Induced humoral immunity. & $\begin{array}{l}\text { Yuasa et al. } \\
(2002)\end{array}$ \\
\hline $\begin{array}{l}\text { Recombinant ETNNV- } \\
\text { CP (Epinephelus } \\
\text { tauvina nervous } \\
\text { necrosis virus-capsid } \\
\text { protein) }\end{array}$ & IM & - & $\begin{array}{l}\text { Induced stronger humoral immunity than formalin } \\
\text { inactivated nodavirus. No challenge test was } \\
\text { performed. }\end{array}$ & $\begin{array}{l}\text { Hegde, Lam } \\
\& \operatorname{Sin}(2005)\end{array}$ \\
\hline $\begin{array}{l}\text { Formalin inactivated } \\
\text { nodavirus }\end{array}$ & IP & $\begin{array}{l}60 \% \text { higher survival rate of } \\
\text { brown-marbled grouper } \\
\text { challenged with } 10^{6.5} \\
\text { TCID }_{50} / \text { fish of OSGBF1E }\end{array}$ & Induction of humoral immunity. & $\begin{array}{l}\text { Pakingking Jr } \\
\text { et al. (2010) }\end{array}$ \\
\hline $\begin{array}{l}\text { Recombinant capsid } \\
\text { protein, recAHNV-C }\end{array}$ & IP & $\begin{array}{l}29 \% \text { higher survival rate of } \\
\text { juvenile turbot (Scophthalmus } \\
\text { maximus) challenged with }\end{array}$ & $\begin{array}{l}\text { Fishes vaccinated with plasmid DNA expressing the } \\
\text { recombinant capsid protein were not protected as the } \\
\text { plasmid DNA only induced cellular but not humoral }\end{array}$ & $\begin{array}{l}\text { Sommerset et } \\
\text { al. (2005) }\end{array}$ \\
\hline
\end{tabular}




\begin{tabular}{|c|c|c|c|c|}
\hline & & $10^{6} \mathrm{TCID}_{50} / \mathrm{ml} \mathrm{AHNV}$ & immunity. & \\
\hline $\begin{array}{l}\text { Formalin inactivated } \\
\text { SGWak97 }\end{array}$ & IP & Not reported & Inactivated SGWak97 induced humoral immunity. & $\begin{array}{l}\text { Pakingking Jr } \\
\text { et al. (2009) }\end{array}$ \\
\hline $\begin{array}{l}\text { Recombinant rT2 } \\
\text { SJNNV-CP } \\
\text { (Scophthalmus } \\
\text { maximus nervous } \\
\text { necrosis virus-capsid } \\
\text { protein) }\end{array}$ & IP & $\begin{array}{l}\sim 36 \% \text { higher survival rate of } \\
\text { humpback grouper challenged } \\
\text { with } 6.3 \times 10^{7} \mathrm{TCID}_{50} / \text { fish, } \\
\text { respectively }\end{array}$ & Induced humoral immunity. & $\begin{array}{l}\text { Húsgağ et al. } \\
(2001)\end{array}$ \\
\hline $\begin{array}{l}\text { Chitosan-encapsulated } \\
\text { DNA vaccine (CP- } \\
\text { pNNV) }\end{array}$ & Oral & $\begin{array}{l}55 \% \text { higher survival rate of } \\
\text { juvenile European seabass } \\
\text { (Dicentrarchus labrax) } \\
\text { challenged with } 10^{6} \\
\text { TCID }_{50} / \text { fish }\end{array}$ & $\begin{array}{l}\text { CP-pNNV failed to induce humoral immunity but } \\
\text { activated interferon pathway and cell-medicated } \\
\text { cytotoxicity. }\end{array}$ & $\begin{array}{l}\text { Valero et al. } \\
(2016 b)\end{array}$ \\
\hline $\begin{array}{l}\text { Chitosan conjugated } \\
\text { DNA vaccine pcDNA- } \\
\text { XSVAS }\end{array}$ & Oral & $\begin{array}{l}\text { Approximately } 50 \% \text { higher } \\
\text { survival rate of prawn } \\
\text { challenged with crude extract } \\
\text { of prawn with WTD. }\end{array}$ & $\begin{array}{l}\text { XSV with nodavirus caused white tail disease (WTD) } \\
\text { in prawn. The challenge experiment shall consider } \\
\text { using isolated virus instead of crude one. }\end{array}$ & $\begin{array}{l}\text { Ramya et al. } \\
(2014)\end{array}$ \\
\hline $\begin{array}{l}\text { Recombinant yeast } \\
\text { expressing RGNNV- } \\
\text { CP (red-spotted } \\
\text { grouper necrosis virus } \\
\text { capsid protein) }\end{array}$ & Oral & - & $\begin{array}{l}\text { Induced humoral immunity in mice. No challenge test } \\
\text { was performed. }\end{array}$ & $\begin{array}{l}\text { Kim et al. } \\
(2013)\end{array}$ \\
\hline $\begin{array}{l}\text { Artemia-encapsulated } \\
\text { recombinant pET24a- }\end{array}$ & Oral & $\begin{array}{l}\sim 34 \% \text { higher survival rate of } \\
\text { grouper larvae challenged }\end{array}$ & Induced humoral immunity & $\begin{array}{l}\text { Lin et al. } \\
(2007)\end{array}$ \\
\hline
\end{tabular}




\begin{tabular}{|c|c|c|c|c|}
\hline $\begin{array}{l}\text { NNV VP E. coli } \\
\text { expressing nodavirus } \\
\text { capsid protein }\end{array}$ & & $\begin{array}{l}\text { with } 10^{5} \mathrm{TCID}_{50} / \text { fish, } \\
\text { respectively }\end{array}$ & & \\
\hline $\begin{array}{l}\text { Inactivated bacteria } \\
\text { encapsulated dsRNA of } \\
M r \mathrm{NV} \text { and XSV }\end{array}$ & Oral & $\begin{array}{l}M r \mathrm{NV} \text { challenge } 24 \mathrm{~h} \text { and } 72 \\
\mathrm{~h} \text { post-feeding showed } \\
\text { relative percent survival of } \\
80 \% \text { and } 75 \% \text { respectively }\end{array}$ & $\begin{array}{l}\text { Protection through RNA interference with capsid and } \\
\text { B2 genes of } M r N V \text {, and capsid gene of XSV. }\end{array}$ & $\begin{array}{l}\text { Naveen } \\
\text { Kumar, } \\
\text { Karunasagar } \\
\& \\
\text { Karunasagar } \\
(2013)\end{array}$ \\
\hline $\begin{array}{l}\text { Solid lipid } \\
\text { nanoparticles } \\
\text { encapsulated binary } \\
\text { ethylenimine } \\
\text { inactivated nodavirus }\end{array}$ & $\begin{array}{l}\text { Bath and } \\
\text { Oral }\end{array}$ & $\begin{array}{l}45 \% \text { higher survival rate of } \\
\text { grouper larvae challenged } \\
\text { with } 1 \times 10^{6} \mathrm{TCID}_{50} / \mathrm{ml} \\
\text { HGNNV }\end{array}$ & $\begin{array}{l}\text { Simple vaccination procedure that fit for larvae. Both } \\
\text { routes of vaccinations induced pro-inflammatory } \\
\text { cytokines expression, type I IFN response, humoral } \\
\text { immunity and cellular immunity. }\end{array}$ & $\begin{array}{l}\text { Kai \& Chi } \\
(2008) \text {; Kai, } \\
\text { Wu \& Chi } \\
\text { (2014) }\end{array}$ \\
\hline $\begin{array}{l}\text { Recombinant } M r \mathrm{NV} \\
\text { capsid protein }\end{array}$ & Bath & $\begin{array}{l}\text { Immersion for } 24 \mathrm{~h} \text { followed } \\
\text { by } M r \mathrm{NV} \text { challenge showed } \\
76.03 \% \text { survival in } 15 \text { days } \\
\text { post-challenge }\end{array}$ & $\begin{array}{l}\text { Protection is believed to be through upregulation of } \\
\text { prophenoloxidase, superoxide anion and SOD activity. }\end{array}$ & $\begin{array}{l}\text { Farook et al. } \\
(2014 b)\end{array}$ \\
\hline
\end{tabular}

\section{Notes:}

IM - intramuscular injection; IP - intraperitoneal injection; Oral - oral feeding; Bath - immersion 